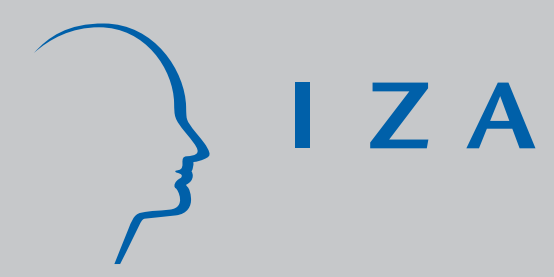

IZA DP No. 2344

Inequality and Growth in Rural China:

Does Higher Inequality Impede Growth?

Dwayne Benjamin

Loren Brandt

J ohn Giles

September 2006 


\title{
Inequality and Growth in Rural China: Does Higher Inequality Impede Growth?
}

\author{
Dwayne Benjamin
}

University of Toronto

Loren Brandt

University of Toronto

John Giles

Michigan State University

and IZA Bonn

\section{Discussion Paper No. 2344 \\ September 2006}

\author{
IZA \\ P.O. Box 7240 \\ 53072 Bonn \\ Germany \\ Phone: +49-228-3894-0 \\ Fax: +49-228-3894-180 \\ E-mail: iza@iza.org
}

\begin{abstract}
Any opinions expressed here are those of the author(s) and not those of the institute. Research disseminated by IZA may include views on policy, but the institute itself takes no institutional policy positions.

The Institute for the Study of Labor (IZA) in Bonn is a local and virtual international research center and a place of communication between science, politics and business. IZA is an independent nonprofit company supported by Deutsche Post World Net. The center is associated with the University of Bonn and offers a stimulating research environment through its research networks, research support, and visitors and doctoral programs. IZA engages in (i) original and internationally competitive research in all fields of labor economics, (ii) development of policy concepts, and (iii) dissemination of research results and concepts to the interested public.
\end{abstract}

IZA Discussion Papers often represent preliminary work and are circulated to encourage discussion. Citation of such a paper should account for its provisional character. A revised version may be available directly from the author. 


\section{ABSTRACT}

\section{Inequality and Growth in Rural China: Does Higher Inequality Impede Growth?*}

We explore the relationship between the level of village inequality in 1986, and the subsequent growth of household incomes from 1986 to 1999. Using a detailed householdlevel data set from rural China, we find robust evidence that initial inequality is negatively related to subsequent household income growth. We are able to address a number of econometric issues that affect the use of aggregate data for this exercise, especially measurement error and aggregation: Our results strongly suggest that village inequality has an external adverse impact on household-level income trajectories. However, once we account for possibly fixed village-level unobserved heterogeneity, we find no evidence that changes in inequality are correlated with household income growth: Whatever factor drives the inequality-growth relationship only operates in the "long run." We explore several possible avenues by which initial inequality - or an unobserved variable correlated with it - affects household income growth. While we do not find the precise mechanism, our findings point toward a class of explanations based on collective choice (like the provision of public goods or determination of local taxes), and away from credit-market based explanations.

JEL Classification: $\quad 012,015, \mathrm{P} 20$

Keywords: inequality, growth, rural China, panel data

Corresponding author:

John Giles

Department of Economics

Michigan State University

110 Marshall-Adams Hall

East Lansing, MI 48864

USA

E-mail: gilesj@msu.edu

\footnotetext{
"This draft has benefited from considerable feedback at many workshops and conferences over the past two years, when it began circulation under the title, "The Dynamics of Inequality and Growth in Rural China: Does Higher Inequality Impede Growth" (April 9th, 2004). We especially appreciate comments from the following people: Daron Acemoglu, Oriana Bandeira, Abhijit Banerjee, Pranab Bardhan, Paul Beaudry, Tim Besley, Belton Fleisher, Steven Haider, Joe Kaboski, Ashley Lester, Albert Park, Nancy Qian, Yingyi Qian, Martin Ravallion, Scott Rozelle, John Strauss, Alessandro Tarozzi, and Kathy Terrell. We also thank conference and seminar participants at: ANU, Beijing University (CCER), UC-Davis, UCLA, the CIAR, Duke, LSE, MIT/Harvard, Michigan State, Ohio State, the NBER, Toulouse, Waterloo, and Western Ontario, and the William Davidson Institute. Benjamin and Brandt are grateful to the Social Sciences and Humanities Research Council for financial support, while Giles is grateful for support from Michigan State, and the National Science Foundation (SES0214702).
} 


\subsection{Introduction}

I

nequality increased in rural China during the period of economic reform which began more than twenty-five years ago: The Gini coefficient is now around 0.45 , versus 0.30 in the mid1980s, and somewhere between 0.20 and 0.25 in the pre-reform period. With broadly improving living standards, there was initially little concern over the rise in income inequality. But levels of inequality now exceed the comfort levels of many policy observers. ${ }^{1}$ Aside from plausible concerns over political unrest, is there evidence that higher inequality can damage economic outcomes, like future growth? Past research on growth and inequality suggests so, but there is debate on the nature and robustness of cross-country evidence, and questions about the applicability of micro-based studies drawn from other countries.

China is an excellent laboratory to explore potential linkages between inequality and growth, and not just because there has been significant time-series movement of the two key variables. Thousands of villages comprise the political and economic building blocks of rural China, and these villages began the reform period with different levels and distributions of endowments, village institutions, and culture. Our objective is to determine whether these initial village conditions-notably the level of inequality-are correlated with the subsequent post-reform economic development of households living in those villages. While our analysis bears on the current understanding of inequality-growth linkages in China, our results also inform more general discussions of whether and how inequality can affect the evolution of economic outcomes.

We employ a household survey that tracks a panel of 100 rural villages from 1986 to 1999, including a subset of panel households. This survey has two key benefits. First, with access to household-level data across several time periods, we can construct a rich, comparable panel of villages that can be used to address a host of econometric and empirical issues that dog those researchers using aggregate cross-country data. We use this village-level data set to estimate a village-level regression of growth on initial inequality that serves as the organizing principle in our empirical work. Second, and most importantly, by exploiting the household dimension of the panel, we can link the evolution of household-level welfare to initial conditions in the village. This allows us to better establish whether village-level inequality exerts a negative externality on household income growth, and also to determine whether inequality affects households differentially within the same village.

\footnotetext{
${ }^{1}$ Official concern with rising inequality is evident in the official aim of "creating a harmonious society", articulated in the $10^{\text {th }}(2001-2005)$ and $11^{\text {th }}(2006-2010)$ Five-Year Plans. See the UNDP (2005), World Bank (2003), and Hutzler (2003) for more general discussions of policy concern with rising inequality.
} 
Why might local inequality affect household income growth? The two channels typically proposed operate either through imperfect credit markets, or the political process. We suggest a number of reasons why these factors might operate at the level of Chinese villages. We next describe the "ideal experiment" that would enable us to identify the effect of inequality on growth: A Chinese Robin Hood assigns initial incomes (or factor endowments) to households within villages, setting them on their way through the reform process. With this as a benchmark, we discuss a long list of potential econometric problems that might plague our regression of income growth on initial village conditions. We address two main problems: 1) Measurement error; and 2) Unobserved heterogeneity. The first is relatively easy to deal with through measurement-error-inspired instruments that we construct using the household-level data. The second is more difficult, and we discuss the assumptions that must hold for a second set of instruments to serve their purpose. Since the instruments may be inadequate, we also employ village-fixed effects to absorb the heterogeneity that may contaminate the cross-section regression. We thus provide estimates using procedures that mirror those in the broader literature.

We find robust evidence of an economically significant negative link between initial inequality and subsequent growth: villages with higher inequality in 1986 grew more slowly over the next thirteen years. We do not, however, find that rising inequality is related to the growth trajectory: In village fixed-effects specifications, there is no statistical relationship between inequality and growth. This suggests that the mechanism linking growth to inequality operates "in the long run," and is differenced-out over shorter periods of time. In addition to growing slower, we also find that more unequal villages had the slowest non-agricultural development, and that economic activity was tilted more towards agriculture over the period. In many respects, we find that low inequality mimics the effect of village education, leading to higher income growth, especially of non-farm incomes. To better understand the long-run relationship, we return to the household-level, to see whether village inequality interacts with household initial conditions: Are poor families at the greatest disadvantage in a high inequality village? We find no evidence of this. The inequality externality seems to affect all households the same way.

To better understand the possible channels by which inequality might affect growth, we finish with a set of explorations of relationships between village "institutions" and initial inequality. While we do not find a "smoking gun," our combined evidence allows us to rule out the simplest credit-market based explanations, and points instead towards political-economy / public-choice based explanation. We therefore cast a wide net, trying to find the key features of local taxation or public goods that characterize more equal villages. Again, we don't find a single factor that explains everything, but we are able to rule out several competing hypotheses, such as 
the importance of Township and Village Enterprises (TVEs), in promoting non-farm income growth in more equal villages. Although we don't find that the level of taxation or public expenditure is correlated with initial inequality, we do find that low inequality villages have more progressive taxes. This provides a hint that village governance may be affected by income inequality.

What do we learn? Most importantly, we establish a robust set of "facts" that need to be incorporated into stories linking growth to inequality in rural China. These facts do not point to a specific simple story, but they weigh against others, especially those that rely on heterogeneous outcomes for households with different resources, such as imperfect credit markets. Nothing in our findings suggests that short-run increases in inequality have adverse effects on economic growth. To this extent, current concern about rising inequality may be exaggerated. However, our results show a longer run link between inequality and growth that is hard to dismiss. To the extent that high inequality affects local choices, possibly in the provision of public goods like education, or in setting taxes that fall heavily on the poor, Chinese officials have much to be worried about.

\subsection{Conceptual Framework}

Our core regression specifies village-level growth as a function of initial inequality and covariates, analogous to the typical cross-country regressions:

$$
\Delta \ln y_{v t}=\alpha_{0}+\alpha_{1} \ln y_{v t-1}+\alpha_{2} X_{v t-1}+\beta_{v} G_{v t-1}+u_{v t}
$$

where $\Delta \ln y_{v t}$ is the growth rate of mean village per capita income for village $v$ between periods $t-1$ and $t$; $\ln y_{v t-1}$ is lagged (or initial) log per capita income, $X_{v t-1}$ is a vector of village-level controls (dated period $t-1$ ), and the main variable of interest is $G_{v t-1}$, a measure of village income inequality, such as the Gini coefficient, in period $t-1$.

The key interpretation issue is why $\beta_{v}<0$, i.e., why might higher inequality villages have lower average growth rates? ${ }^{2}$ Growth in village average income ultimately depends on the underlying household relationship:

$$
\Delta \ln y_{h v t}=\gamma_{0}+\gamma_{1} \ln y_{h v t-1}+\gamma_{2} X_{h v t-1}+\gamma_{3} \ln y_{v t-1}+\gamma_{4} X_{v t-1}+\beta_{h} G_{v t-1}+u_{h v t}
$$

\footnotetext{
${ }^{2}$ See Aghion et al (1999) and Lloyd-Elllis (2003) for excellent summaries of the cross-country inequality and growth literature, with detailed discussions of the theoretical linkages between inequality and growth.
} 
The additional subscript, $h$, indexes households in village $v$, and household-level variables are defined analogously to those at the village-level. In this specification, household income growth depends on own initial resources, as well as both level and distribution of aggregate resources. We could also allow initial income to have a more general, and potentially nonlinear, effect on subsequent growth, by including a more general $f\left(y_{h v t-1}\right)$ in the regression.

What ideal experiment generates the data that would enable us to consistently estimate $\beta_{h}$ ? Imagine a Chinese "Robin Hood" stealing from a rich family, and giving to a poor one. ${ }^{3}$ This will have two effects. First, it changes the initial incomes of the two households. Second, it reduces overall inequality, without changing average village income. The first effect will be captured directly in the household-level regression, but at the village level, the two effects will be reflected only in the Gini coefficient.

In order to evaluate the potential consequences of Robin Hood's intervention, begin by assuming that the distribution of village resources (level and inequality) has no independent effect on household income growth. Only household resources matter. The impact of the redistribution depends on the extent to which own resources (i.e., $y_{h v t-1}$ ) affect the subsequent growth trajectory. There are a number of possibilities. With well-functioning credit markets, it may be the case that own-resources have no effect on subsequent growth, in which case the redistribution is neutral. At the village level, we would not expect the dispersion of household resources to be informative about the patterns of household growth. But with imperfect movement of capital across households, there are a number of possible outcomes, depending on how own-resources determine subsequent growth. It may be the case that growth is increasing in own-resources, though at a decreasing rate. The more poor households that exist (for a given average level of resources), the more slow-growing households there are. In this case, income redistribution increases growth by transferring resources to the poor, unleashing their growth potential (by more than rich households' growth is reduced). ${ }^{4}$ At the village-level, high inequality would proxy for a high number of slow-growing, poor households. On the other hand, we may observe household convergence, whereby poor households actually grow faster. For a given level of village resources, and diminishing marginal productivity of own-resources, lower inequality would be associated with lower average growth rates. Inequality has no independent effect on growth, but

\footnotetext{
${ }^{3}$ One candidate for "Chinese Robin Hood” is Song Jiang (宋江) and the 108 bandits from Mount Liang (梁山) who feature in the Chinese literary classic The Water Margin (水湤传) (Shi and Luo, 1365c). The Water Margin is also known under the following alternative English titles as All Men are Brothers (Buck, 1933), Outlaws of the Marsh (Shapiro, 1981), and The 108 Heroes.

${ }^{4}$ The investment opportunities include expansion of family businesses (Stiglitz, 1969, and Banerjee and Newman, 1993), or education (human capital).
} 
in the aggregate, higher inequality is associated with having more poor households that would (by whatever "convergence" mechanism) have higher rates of growth. Clearly, more complex predictions can be made if there are non-linearities in the return to initial income. ${ }^{5}$

In these examples, inequality has no independent effect on household income growth, and would be insignificant in a household-level regression controlling for household resources. The impact of inequality at the village level is an "artifact" of aggregation, whereby the Gini proxies for the underlying heterogeneity of initial household incomes, that, in turn may be correlated with subsequent household growth rates. We could observe $\beta_{v} \neq 0$, even if $\beta_{h}=0$. As noted by Ravallion (1998) and Deaton (2003), the aggregate-level results may confound true direct effects of inequality with those that are an artifact of aggregation. The resulting bias can go either way, and reinforces the value of estimating the regression at the household level.

Why might inequality exert a negative externality on household income growth, i.e., why might $\beta_{h}<0$ ? In this case, Robin Hood's intervention affects households besides those immediately involved in his redistribution. One channel is through factor markets. Higher income inequality (or inequality of land, human, or physical capital) may be associated with imperfect competition or other impediments to factor market development (such as credit markets), lowering factor returns for the poor. An important strand of empirical research on India has identified a number of channels by which lower inequality, especially improved access to land by the poor, affects factor markets (like labor markets) and tilts the terms of trade towards the poor. ${ }^{6}$

Another channel is through village political economy: unequal villages may make different collective choices. For example, high-inequality villages may adopt more progressive tax structures, as low-income households pressure for redistribution in ways that inhibit growth. This is the conventional taxation-based story offered by Alesina and Rodrik (1994), Benabou (1996), and Persson and Tabellini (1994). Alternatively, the greater homogeneity (equality) of households may facilitate consensus for more efficient tax systems, and higher investment in public goods and services. ${ }^{7}$ There may also be links between the distribution of income, levels of education, and the provision of public education. ${ }^{8}$

\footnotetext{
${ }^{5}$ Another explanation combines imperfect credit markets with increasing returns (Kaldor, 1956 and 1957). Here, concentration of wealth among rich households enhances investment and growth.

${ }^{6}$ Notable examples include: Besley and Burgess (2000), Banerjee, Mookherjee, Munshi, and Ray (2001), Banerjee, Gertler, and Ghatak (2002), and Banerjee and Iyer (2005).

${ }^{7}$ Several recent papers suggest that collective action and provision of public goods may be complicated by high levels of inequality within communities. See for example, Alesina and La Ferrara (2000), Bardhan, Ghatak and Karaivanov (2006), Dayton-Johnson (2000), Dayton-Johnson and Bardhan (2002), and Khwaja (2004). With respect to public finance, Sokoloff and Zolt (2005) find that high inequality is correlated with
} 
One important question is whether such political-economy processes operate at the village-level in China? Institutionally, the village is an important administrative unit, with many collective decisions made at this level. ${ }^{9}$ Over the period we examine, village governments controlled levers connected to several important variables that could affect household income: They allocated land across households, set local taxes, and made investment decisions over local infrastructure, like irrigation maintenance, road construction and maintenance, construction of elementary schools and provision of water. ${ }^{10}$ In an agricultural economy with significant returns to education (at least in non-agricultural activities), decisions about the provision of public goods can affect the overall success of households. Given the heterogeneity in the evolution of village governance, there are a number of political economy channels that could lead to more unequal villages following different growth trajectories.

The focus of our empirical investigation is the estimation of the extent to which inequality exerts a purely "external" and independent effect on household income growth. While the village-level regression is more manageable, especially in addressing a myriad of econometric issues, the external effect of inequality is best informed by household-level data. More fundamentally, the observed correlation between inequality and growth may be driven by factors other than the exogenous differences in inequality arising from the "Robin Hood" experiment. We now discuss why it may be difficult to draw causal inferences from this correlation, and potential strategies that can help mitigate these concerns.

\subsection{Econometric Issues}

Our empirical strategy exploits the RCRE survey, based on an initial sample of approximately 100 villages, including a significant subset of panel households followed from 1986 to 1999 . An obvious way to estimate the effect of inequality on growth is to construct

more regressive taxes, and less funding of local public investments and services. Glaeser (2005) reviews evidence suggesting that unequal societies are less likely to have governments that respect property rights.

${ }^{8}$ See, for example, Benabou (1996), or Lloyd-Ellis (2000). This channel may be especially important if there are externalities associated with the distribution of education in the economy (e.g., Acemoglu (1996)). ${ }^{9}$ Villages are at the lowest rung of the rural administrative hierarchy. Above villages, township and county governments have authority over some fees and taxes, and above the county lies the provincial government. ${ }^{10}$ In a recent survey carried out in a hundred villages in five provinces looking at the effect of recent fiscal reforms, only $21.3 \%$ of village public goods' investment in 2000 was financed by revenue from higher levels of government. The majority of investment came from the village. See Brandt, Rozelle, and Zhang (2005). With the recent tax-for-fee reform carried out between 2002 and 2004, villages largely lost their right to tax. 
village-level averages of the key variables, then estimate village-level regressions analogous to those at the cross-country level:

$$
\Delta \ln y_{v t}=\alpha_{0}+\alpha_{1} \ln y_{v t-1}+\alpha_{2} X_{v t-1}+\beta_{v} G_{v t-1}+u_{v t}
$$

where $\Delta \ln y_{v t}$ is the village growth of per capita income between 1986 and 1999; $\ln y_{v t-1}$ is village initial income in 1986; $G_{v t-1}$ is the Gini coefficient for household per capita income in 1986, and $X_{v t-1}$ are controls for village characteristics in 1986. A key question is whether the OLS coefficients bear any relationship to the externality effect we wish to identify. There are several reasons why this may not be the case, and to guide the discussion, we decompose the error term:

$$
u_{v t}=\theta_{v}+\lambda_{v}+v_{v t}+\varepsilon_{v t}
$$

This decomposes $u_{v t}$ into two village-level "fixed effects," $\theta_{v}+\lambda_{v}$, one of which may be problematic, and two time-varying components, $v_{v t}+\varepsilon_{v t}$, where one component may pose a statistical difficulty. The econometric exercise is to determine the conditions under which these error components are correlated with the main regressor, $G_{v t-1}$.

\subsection{Time-Varying Sources of Bias}

For simplicity, assume that $\varepsilon_{v t}$ is "well-behaved," so that it represents unobservable determinants of village growth that are uncorrelated with the regressors, $E\left[\varepsilon_{v t} \mid \ln y_{v t-1}, X_{v t-1}, G_{v t-1}\right]=0$. On the other hand, $v_{v t}$ captures time-varying unobservables that may render OLS inconsistent, i.e., $E\left[v_{v t} \mid \ln y_{v t-1}, X_{v t-1}, G_{v t-1}\right] \neq 0$. There are a variety of reasons why this may be a problem:

- Aggregation: We cannot interpret the coefficient on $G_{v t-1}$ in the village-level regression as the direct "externality" impact of inequality without restrictive assumptions concerning the functional form. Given that we eventually estimate this regression at the household level (specifically to evaluate the importance of aggregation), we set this problem aside.

- Omitted Variables (Time Varying): A variety of factors may be correlated with initial inequality and ultimately affect growth. For example, high inequality villages might have different a economic structure. Shocks (like the collapse of agricultural prices) may reduce the growth experience of these villages, while our blame incorrectly falls on higher 
inequality. Another set of omitted variables may be non-linear functions of initial income: $\ln y_{v t-1}$ may be an insufficient control for initial income, and non-linearities may pile up on the $G_{v t-1}$ coefficient. While we cannot anticipate all possible omitted variables, we make some effort to include a rich set of covariates to soak up heterogeneity of initial conditions, including additional non-linear functions of initial income.

- Measurement Error. There are a number of ways in which measurement error, especially in household income, may generate spurious links between initial inequality and subsequent growth. For example, we might poorly control for initial income. If we underestimate initial income, then mean reversion alone will generate what appears to be "income convergence." This is of no concern to the extent that our focus is inequality. However, if there is a correlation between the level of income and its distribution (maybe poor villages are more equal), then we will misattribute some of the "convergence" to low inequality. Alternatively, the Gini may reflect village-level measurement error, i.e., high Gini's correspond to a greater number of "outlier" household incomes. Such villages may also have inaccurately high levels of initial income (driven by the outliers). With mean-reversion in household incomes, these villages will appear to have lower growth rates, even if there is no link between inequality and growth. Finally, the greater degree of noise in $G_{v t-1}$ may result in conventional attenuation bias. In any case, it is easy to concoct stories linking inequality to growth that are driven by measurement error. As it turns out, measurement error is a relatively straightforward problem to address with instrumental variables. While the instruments may be invalid under some conditions, within the narrow confines of a measurement error model, we only need to find variables that are correlated with initial incomes and inequality, that are themselves independent of the measurement error. Candidate variables include more "robust" measures of inequality (less sensitive to outliers), as well as functions of the initial distribution of factor endowments. More formally, we denote these measurement-errorinspired instruments by $Z_{1 v t-1}$, where the instruments satisfy $E\left[v_{v t} \mid Z_{1 v t-1}, X_{v t-1}\right]=0$, but may not be orthogonal to other components of the error term (like $\theta_{v}+\lambda_{v}$ ). As they may be functions of $y_{h v t}$, there will be limits on the degree to which they are exogenous.

- Attrition. Household attrition may be correlated with both initial inequality and subsequent growth. For example, there may be selective out-migration, whereby households are more likely to leave slow-growing villages. They key question is whether such migration is correlated with initial inequality. If out-migration was more common in the high-inequality, low-growth potential villages, then depending on which households leave, we might observe 
a spurious link between initial inequality and the growth rates calculated on the basis of the initial sample collected in 1986, and the revised (attrition-affected) sample in 1999. In our empirical work, we explore the sensitivity of our results to various accounts for attrition.

\subsection{Village Fixed Effects}

As serious as the correlation between time-varying $v_{v t}$ with $G_{v t-1}$ may be, the most difficult problems concern the village fixed effects, $\theta_{v}+\lambda_{v}$. Again, some of the initial village characteristics that affect growth may be uncorrelated with the covariates (or instrumental variables) of interest (like initial inequality): $\lambda_{v}$. Our problems arise with the possibility that $E\left[\theta_{v} \mid \ln y_{v t-1}, X_{v t-1}, G_{v t-1}\right] \neq 0$. Low inequality itself has no impact on growth, but proxies for some other factor, $\theta_{v}$. No matter how many covariates we include to control for initial conditions, there is always the suspicion that with a better data set, inclusion of a better proxy for $\theta_{v}$ would eliminate the apparent impact of inequality. Perhaps the initial income distribution is related to policies that affect future growth. Controlling for such policies would provide a simple way to evaluate this possibility.

The more feasible problem is addressed by finding a set of instruments, $Z_{2 v t-1}$, that satisfies both $E\left[v_{v t} \mid Z_{2 v t-1}, X_{v t-1}\right]=0$ (uncorrelated with the time-varying error term), and $E\left[\lambda_{v} \mid Z_{2 v t-1}, X_{v t-1}\right]=0$ (uncorrelated with potentially adverse, but less problematic, village fixed effects, $\lambda_{v}$ ). One candidate set of instruments is based on the initial distribution of factor endowments. For historical reasons, it may be the case that land distribution is exogenous to measurement error $\left(v_{v t}\right)$, and unobserved policies in existence in the village $\left(\lambda_{v}\right)$. In this example, we require the land distribution to affect growth only through its effect on income inequality, with no independent effect on growth. The exclusion restriction fails if the land distribution is also correlated with $\theta_{v}$. It is plausible that we can use such variables as instruments to address some of the potential omitted variables problems $\left(\lambda_{v}\right)$, but equally plausible that we can never rule out the potential existence of $\theta_{v}$.

What is the specific nature of $\theta_{v}$ that worries us? Suppose that $\theta_{v}$ is a taste or predisposition for low inequality (egalitarian-oriented villages). This is of concern only if $\theta_{v}$ is also related to growth, for example, if egalitarian villages are more likely to invest in schools (or other growth-enhancing public goods). From an interpretation standpoint, if this drives the inequality-growth relationship, then our conclusions will only be accurate from an "historical" 
perspective: unequal villages in our sample grew more slowly, and this initial inequality was causally related to growth (in a limited sense). However, if it is the underlying taste for inequality $\left(\theta_{v}\right)$ that drives growth, then the Robin Hood "experiment" would not affect the growth trajectory. If we controlled for $\theta_{v}$, changing inequality would have no impact on growth. Rising inequality would be of no concern for growth, even if initial inequality mattered. So while we could confidently conclude that low inequality villages grew faster, if unobserved "egalitarianism" was the driving force, we could draw no conclusions from the current increase in rural inequality. Ideally, we would like to disentangle the impact of actual inequality from unobserved "tastes" for low inequality.

One way to accomplish this is by employing village fixed effects, and using time-varying income growth and changes in inequality to identify causal links between inequality and growth. With that estimator, we can exploit time-varying information on village incomes from 1986 to 1999, to determine whether the timing of changes in inequality line up with changes in growth. We conduct this exercise, but it is important to highlight the potential problems for which the fixed effects estimator is no panacea:

- Measurement Error. Measurement error problems that plague levels may be worsened in the panel. For example, while the village Gini's in a given year may be measured with noise, changes in inequality will be even noisier, leading to greater attenuation bias. To some extent, these problems can also be addressed by measurement-error-inspired instruments. But that doesn't change the fact that there may be less information in the timing of changes in inequality and growth than we can obtain from the longer run cross section.

- Simultaneity. The panel-based fixed-effects estimator essentially estimates the relationship between growth and changes of inequality. The reverse relationship was the focus of Kuznets (1955) research (The "Kuznets curve"). Growth may affect inequality, in which case we may observe a positive relationship between the two variables, depending on the position along the Kuznets curve. To some extent, this can be addressed through instrumental variables, as well as independent investigation of the Kuznets relationship.

- Dynamic Issues. The fixed-effects specification entails estimation of a dynamic panel data model, with a lagged dependent variable (initial income). As noted by Anderson and Hsiao (1982), and Arellano and Bond (1991), this is subject to its own mis-specification. There are a variety of strategies one can employ to address problem. A simple one is to find instruments that help predict initial income, but which are independent of the error term. Instead of various lags of initial income, our measurement-error-inspired instruments have the positive 
side-benefit of addressing the Arellano and Bond problem. A more serious potential problem is the general mis-specification of dynamics. We do not really know how inequality affects growth (if it does at all). It may be that a true causal relationship exists and is reflected in the long-run relationship estimated by the OLS cross-section. However, fixed effects (or firstdifferences) require that there be an instantaneous link between contemporaneous changes in inequality and growth. If this is not the case, then we may find no relationship between inequality and growth in the fixed effects specification - not because there is no long run relationship--but because there is no such relationship in the short run. Indeed, this is the argument used by Easterly (2005), among others, to dismiss the panel data evidence. In the end, it may be difficult to reconcile conflicting fixed effect and OLS evidence.

\subsection{Household and Village Characteristics}

\subsection{The Data}

Our data come from annual household surveys conducted by the Survey Department of the Research Center on the Rural Economy (RCRE). Household-level surveys from 100 villages in nine provinces (Anhui, Gansu, Guangdong, Henan, Hunan, Jiangsu, Jilin, Shanxi and Sichuan) are matched with corresponding village-level data. ${ }^{11}$ Sample sizes are between 30 and 130 households per village. Originally planned as an annual longitudinal survey, by 1999 there was significant attrition of households, on the order of 30 percent. A "representative" household replaced each lost household. We are able to follow a subset of continuously surveyed households in 82 of the villages. To construct village-level variables, we use data from 1986 to 1999 that includes between 7,000 and 8,000 households per year.

The survey collected detailed household-level information on incomes and expenditures, education, labor supply, asset ownership, land holdings, savings, formal and informal access to credit, and remittances. In common with the NBS Rural Household Survey, respondent households keep daily diaries of income and expenditure, and a resident administrator living in the county seat visits with households once a month to collect information from the diaries. The large number of households surveyed from each village and the lengthy span of the survey enables us to track the evolution of consumption, incomes and inequality during a time of

\footnotetext{
${ }^{11}$ The complete RCRE survey covers over 22,000 households in 300 villages in 31 provinces and administrative regions. RCRE's complete national survey is 31 percent of the annual size of the NBS Rural Household Survey. By agreement, we have obtained access to data from 9 provinces, or roughly one third of the RCRE survey.
} 
changing market access and development in rural China. Of particular importance for our purposes, we are able to track a panel of villages, even where there has been household attrition.

A variety of definitions are worth clarifying, though further details related to attrition and comparisons of the RCRE data source with other data from rural China can be found in the main text and extensive appendices of Benjamin, Brandt, and Giles (2005). First, household membership is defined on the basis of residency and registration. Second, income is calculated as the sum of net income (gross revenue less current expenditures) from agriculture, farming sidelines (e.g. animal husbandry and livestock), family-run businesses, plus wage income, and transfers. We calculate the value of farm output that is not sold, and thus largely consumed (or stored) by the household, at market prices. Our measure of household income also ignores taxes and fees. Finally, we deflate all income and expenditure data into 1986 prices using the NBS rural consumer price index for each province.

\subsection{Trends in Per Capita Income and Inequality}

Household-level descriptive statistics spanning the period from 1987 to 1999 are reported in Table $1 .^{12}$ Over this period, rural per capita incomes rose less than 2 percent per annum, modest compared to reported national GDP growth rates over the same period. In part, lower growth among rural households reflects the sharp drop in agricultural commodity prices which occurred after 1996, and its adverse effect on farm incomes. Farming was nearly universal (94 percent in 1999), but between 1987 and 1999, households diversified into non-agricultural family businesses and wage employment. These two sources of income account for much of the observed income growth, and helped offset the decline in agricultural income. Income from family business grew by an average of 4.8 percent per year, and increased as a share of total income from 16 to 23 percent. The share of income from wage employment, in both local and migrant labor markets, increased from 25 to 39 percent of income and grew by 5.4 percent per year over the period from 1987 to 1999.

Overall inequality increased by 16 percent, as the Gini coefficient rose from 0.32 to 0.37 . The expansion in off-farm, non-agricultural opportunities, and decline in barriers to mobility reduced the role of regional, provincial, and village differences in generating inequality, but widened differences between households in the same village. Between 1987 and 1999, the

12 See Benjamin, Brandt, and Giles (2005) for a more detailed discussion of the data, including a comparison of the RCRE data with other data sources. Ravallion and Chen $(1999,2005)$ examine inequality and poverty trends in China using the National Bureau of Statistics household surveys. 
contribution of within-village inequality to overall inequality increased from 50 to 58 percent. Figure 1 provides the distribution for household average annual growth rates over the period.

\subsection{Village Level Variables}

In our analyses of the growth-inequality relationship, we wish to reduce the influence of measurement error and high-frequency shocks to income. Accordingly, we construct three year averages of all variables for both household and village level analyses. ${ }^{13}$ In Table 2, we observe considerable variation in the initial period (1986 to 1988) average income per capita, and in growth rates of income per capita between period 1 and period 4 (1997 to 1999). Contrary to the image of relative equality of incomes within villages in the 1980s, we find considerable variation in initial per capita income in Figure 2. Initial village inequality, on the other hand, ranges from a low of 0.11 to a high of nearly 0.46 , with most of the support between 0.15 and 0.30 .

In our village-level regression models, we include average years of education per working-age adult as a control for average human capital. There is a significant gap of almost 1.7 years' education between "low" and "high" education villages (i.e., 4.7 versus 6.4 years of education for the first and third quartiles). Differences across villages in the stock of initial human capital may be driven by differences in local provision of elementary education and proximity to middle schools, or differences in the private returns to education. The initial structure of the local economy is also likely to have a considerable impact on village growth prospects, and thus we also include the average share of income over the three year period earned from agricultural crops (both cash crops and grain crops). Again, the inter-quartile range suggests considerable range in the importance of traditional agricultural activities for village incomes.

\subsection{Instrument Sets for Village Level Analyses}

Summary statistics for our potential instruments are shown in Table 2. The instruments are separated into two distinct groups: measurement-error-inspired instruments, and endowmentbased instruments. The instruments, which vary greatly across villages, are used to predict both initial average income per capita, as well as the Gini:

- Measurement Error-Inspired Instruments. The first set of instruments is inspired by efforts to control for classical measurement error that leads to attenuation bias, or to mechanical forms of endogeneity that arise if outliers in household income drive a correlation between growth

\footnotetext{
${ }^{13}$ In Anhui province, eight villages were not added to the survey until 1987, and in Gansu, data from 1988 was missing for one village. For these nine villages, the initial period is calculated using a two-year average. Our results are robust to dropping these nine villages.
} 
and inequality. Potential instruments for initial income per capita include consumption per capita, and average off-farm wage income per capita. In our estimation, we use average offfarm wage income per capita, under the assumption that the most important source of measurement error for income per capita occurs in the valuation of income from homeproduced grain and agricultural commodities that are not marketed. Wage income per capita will be strongly correlated with income per capita, but not with errors in measurement from home production. For the Gini coefficient, potential instruments include the consumptionbased Gini, and other measures of dispersion (the ninety/ten and the seventy-five/twenty-five income ratios). These variables should be correlated with the income Gini coefficient, but uncorrelated with outliers of household income. In our analyses, we use the ninety/ten and seventy-five/twenty-five income ratios, especially for their robustness to outliers. Note that the underlying assumption with these instruments is that measurement error is the only problem generating a correlation between the Gini and the error term, and the validity of the instruments is predicated on this assumption.

- Endowment-Inspired-Instruments: Land. Measures of average land per capita, and its distribution within villages, offer promise of an exogenous (or at least, long pre-determined) measure of the distribution of endowments within villages. ${ }^{14}$ With the implementation of the household responsibility system (HRS) and the return of land to family farm management, land was allocated by village leadership in a fairly egalitarian way. ${ }^{15}$ However, there were limits on the degree of land redistribution. Land allocation was typically carried out at the level of a village sub-unit, the small group, which usually consisted of 25-30 households. Village-wide reallocations of land across small groups tended to be infrequent. As a result, differences in land between small groups generated exogenous land inequality within a village. These differences date back nearly twenty years when, in the aftermath of the Great Leap Famine, property rights to land and decisions on land management were decentralized to the production team, the Maoist-era name of the small group. The accumulated effects of differences in average household demographic change across small groups may have further widened these initial differences in endowments. Thus, one source of within village inequality in 1986 derives from inequality in the distribution of land across village small

14 The land distribution has been taken as "relatively" exogenous in several other papers, either as the primary measure of inequality in the growth regression (Alesina and Rodrik (1994), or as an instrument for income inequality (as in Lundberg and Squire (2003)).

15 See Putterman (1993) for a more detailed discussion of institutional change during the reform process. 
groups. ${ }^{16}$ Potential land-endowment based instruments for the income per capita Gini coefficient thus include the Gini for cultivated land per capita, and the coefficient of variation of household dependency ratios. Potential instruments for initial income per capita include cultivated land per capita, "other" land per capita and the village average household dependency ratio. The land-based instruments should be valid in addressing measurement error, under the assumption that measurement error is the only econometric issue. They will also serve as legitimate instruments for income inequality under more general conditions, insofar as land differences between households within a village are not generated by village growth potential, or are correlated with the "taste" for equality. Especially if most variation is generated by differences across small groups, this condition should be satisfied. Even if the land Gini is not a valid instrument, at the very least it gives us a distinct estimate of the impact of inequality on growth which can be compared to our other estimates.

- Endowment-Inspired-Instruments: Productive Assets. A third set of potential instruments, shown in Table 2, is inspired by productive asset endowments in the initial period. After controlling for average village human capital and industry structure, measures of initial assets and their distribution can identify differences in income and the distribution of income across villages. Potential instruments for income include productive assets, share of productive assets managed by the collective, and the average village dependency ratio. The first variable picks up the effect of past investment in productive activity, and the second picks up heterogeneity in village policy promoting productive activity, and in how villages decided to manage village assets with the implementation of the household responsibility system. ${ }^{17}$ Instruments for income inequality include the Gini of productive assets per capita gini, the share of assets managed by the village collective, and the coefficient of variation of household dependency ratios. The impact of the asset distribution should map into the distribution of income per capita across households in the village. The share of productive assets managed by the collective, that could also be an instrument for income per capita,

\footnotetext{
${ }^{16}$ Neither the RCRE survey data, nor any other data source that we are aware of include information on households' small group membership over the period we examine. Small group membership, however, did not change over this period. In 2003, RCRE reported small group identifiers for households for the first time. To assess the contribution of small groups to land inequality, we first run a regression of household land per capita on village identifiers alone, and next run the same regression on small group identifiers. The $\mathrm{R}$-squared for the village dummies alone was 0.503 , while 0.616 when using small group dummies, and an LM test for whether small group effects add explanatory power over village effects is 310.67 with a p-value of 0.0000 . The small group's contribution to land inequality was probably much more important in 1986 than in 2003 because of the gradual evolution of land-transfer rights since the early-1990s.

${ }^{17}$ In addition to deciding how to allocate land among households, villages also had to decide how to dispense of village productive assets, including small enterprises. In some cases, these were retained and managed by the village, and in other cases they were sold off, or allocated amongst households.
} 
identifies heterogeneity across villages in collective participation in the village economy. To the extent that the collective may invest in lumpy production assets used in agriculture, then they may raise the income of more farmers together and thus a higher share of collective ownership may be correlated with less inequality. Alternatively, if access to income from collective assets is distributed equitably, through equal reductions in local taxes and fees or through equitable access to employment opportunity in collective enterprises, then collective asset ownership may be correlated with lower inequality within villages.

- The "Fat" Instrument Set: Asset and Land-Plus Combined. Our final instrument set combines the land and asset instruments described above, and includes additional land-based instruments reflecting both the productivity of village land, and the role of the collective in land management. Additional instruments for initial income, shown in Table 2, include other land (land used for livestock, fisheries, and forest production), the share of households with other land, and shares of arable and other land under collective management. Additional instruments for the distribution of income include: other land interacted with share of households with other land, and shares of arable and other land under collective management. The "Fat" set of instruments most likely pushes the limits of exogeneity, given the requirements that capital affect growth only through its effect on initial income (and its distribution). While they have limitations, over-identification tests should at least determine whether our various instrumenting strategies are internally consistent.

\subsection{Results}

Our first objective is to estimate, and establish the robustness of the empirical relationship between inequality and household income growth.

\subsection{The OLS Relationship}

In Table 3 we show the OLS estimates of equations 2 (household-level), and equation 3 (village-level). Column 1 begins with the household-level estimates, and shows the main result of the paper: in villages with high inequality in the initial period (1986 through 1988), household incomes grew slower than those in villages with low inequality. ${ }^{18}$ This result is not an artifact of aggregation: the regression is estimated at the household level, and we control for household income linearly (in column 1), and non-linearly in column 2. These results also cast doubt on

\footnotetext{
${ }^{18}$ Our household level regression employs cluster-corrected standard errors to account for the mixture of household- and village-level regressors.
} 
simple credit-market explanations, by which the Gini reflects variation across households of the marginal product of capital.

Some of the other coefficients bear comment, as their patterns are common to future specifications. First, household incomes demonstrate convergence over the sample period, with richer households' incomes growing more slowly. Second, we observe an "external" effect of the level - not just inequality - of village income on household income growth: controlling for ownhousehold income, households in richer villages grew faster. Third, incomes grew slower in those villages with a higher initial share of income in agriculture. This reflects those villages' greater exposure to the collapse of crop prices in the late 1990s, and the higher incomes that can be earned off-farm in villages with growing non-agricultural sectors. Finally, after controlling for own-household education, there remains a robust positive effect of average village education levels. This pattern persists in future tables, highlighting the important role of village-level education to the evolution of household incomes. One channel by which inequality could influence growth, is through higher initial investments in primary schools in more equal villages. ${ }^{19}$ Note however, that the effect of inequality remains, even after controlling for education.

While the household level regressions yield the main results of the paper, we conduct most of our empirical and econometric explorations at the village level. The household-level results suggest that the impact of inequality is a village-level phenomenon, and it is easier to explore correlates with inequality, and potential causal mechanisms, at the village level. Figure 3 plots village-level growth against the village-level Gini. The OLS line has a slope of -0.063 , with a statistically insignificant t-value of 1.42 . While the 3 villages with the highest Gini's could dominate the regression (and exaggerate the slope), the non-parametric (Lowess) plot is similar to the OLS line through most of the sample. The regression analogues to Figure 3, with full controls, are shown in the last four columns of Table 3. Column 3 shows the village-level results based only on the panel households (the same sample used in columns 1 and 2). The estimated effect of inequality is negative and statistically insignificant, as in Figure 3. In column 4, we use village means constructed from the entire sample of households, i.e., the panel, those lost to attrition, and their replacements. The results with this sample are basically the same as those based on the more restricted panel-based village data. As at the household-level, we observe village-level convergence of average incomes, a strong positive effect of the initial level of education, and a negative effect of concentration in agriculture.

\footnotetext{
${ }^{19}$ Middle schools and high schools are typically located outside the village in the township or county seat.
} 
We explore the potential importance of selective migration and panel attrition in columns 5 and 6 . In column 5 we add a control for the amount of out-migration from the village that occurred between 1986 and 1999, while in column 6 we add a variable summarizing the extent of attrition of households from the sample. ${ }^{20}$ Neither of these controls is statistically significant, and the key results for the Gini are unaffected. In summary, our OLS results show a strong negative relationship between initial inequality and income growth at the household level, and a weaker negative result at the village level. This mirrors the pattern observed by Ravallion (1998) using the county as a unit of observation, and suggests that the village level regression may understate the impact of inequality on growth, possibly because of issues related to aggregation.

\subsection{Instrumental Variables Estimates}

For reference, we reproduce the base village-level OLS results in the first column of Table 4. In the other columns, we vary the instrument set to address the econometric problems raised in section 3, treating the level (initial village income) and inequality (the Gini) as endogenous. We start by addressing measurement error, using our "measurement error-inspired" instrument set, the 90/10 and 75/25 income ratios, and average wage income per capita. ${ }^{21}$ These instruments, essentially "re-packaged" functions of the distribution of household income, are highly significant in the first stage equations, and generate significantly negative estimates of the impact of inequality on growth. This suggests that the weak OLS estimates suffer from measurement error-induced attenuation bias. From another perspective, the results in column 2 show that "inequality matters," when we use a richer set of inequality measures than the Gini. The coefficient on initial village incomes, on the other hand, is similar to the OLS equation.

In columns 3 through 5, we use the different sets of endowment-based instruments introduced in Section 4. At a minimum, these instruments help address measurement error, and are better for this purpose than using functions of income, like the 90-10 ratio. They also address, in principle, some of the other potentially important endogeneity problems. In column 3 we use our "leanest" set of endowment measures, based on the distribution of land. This instrument set should break possible mechanical links between initial income and its subsequent growth rate. Furthermore, if the land distribution is uncorrelated with those unobserved factors linking inequality to growth $\left(\theta_{v}\right)$, then we can interpret the result as the "causal" effect of inequality on growth: If land inequality is an "accident of history," then its effect on subsequent growth occurs

\footnotetext{
${ }^{20}$ We used the average share of households attritting per year from 1986 to 1999.

${ }^{21}$ Wage income is probably subject to less from measurement error than crop income, for which farm households need to estimate the value of non-marketed agricultural produce that is consumed or stored.
} 
entirely through its impact on initial income inequality. ${ }^{22}$ As a start, the instruments pass the usual specification tests for being minimally acceptable: they are significant predictors in the first stage equations, and they pass conventional over-identification tests. The 2SLS results based on these instruments show a larger adverse effect of inequality, with a coefficient on the Gini of -0.23 . This implies, for example, that an increase in the Gini from 0.20 to 0.30 reduces growth by 2.3 percent. The fact that the coefficient on inequality is larger than with our "measurement inspired" instruments (Column 2) is consistent with the presence of residual measurement error in the income-based instrument set.

We gain further interpretation by examining the reduced form that underlies the 2SLS results. The first columns of Table 5 show the reduced form associated with "lean land instruments" for each endogenous variable: initial village income, the initial level of inequality, and subsequent income growth. The underlying "experiment" we wish to exploit is illustrated in columns 2 and 3. First, initial land inequality is significantly related to initial income inequality. Second, we see in column 3 that villages with higher land inequality grew significantly slower. Our structural interpretation (via 2SLS) is that the entire effect of land inequality is through its impact on the income inequality, which in turn reduces growth, by whatever mechanism or channel.

Returning to Table 4, Column 4, we use capital, instead of land-based, assets as instruments. This instrument set addresses measurement error without many strong assumptions, but requires strong assumptions to address some of the other issues. Despite being distinct from the land distribution, the asset-based instruments yield an almost identical estimate of the effect of inequality on growth. In column 5, we use the "fat" instrument set, combining the land and capital instruments, and generating a similar, but more precisely estimated, negative coefficient on initial inequality. The reduced form for the "fat" instruments is shown in the last three columns of Table 5. In column 8, the first stage for the Gini, only the land Gini is individually significant among the instruments, though the joint F-statistic indicates that, jointly, the excluded instruments are significant predictors of initial inequality. While only significant at the 10 percent level, note the coefficient on the share of assets managed by the collective (village): in villages where the local government owns more of the local assets, initial income inequality is lower. The corresponding effect of this variable on growth is positive but insignificant. This is admittedly weak evidence linking "institutions" to growth, but if this variable reflects a village taste for "collective ownership" or coordination, it lines up with both lower initial inequality and higher

\footnotetext{
${ }^{22}$ Recall that the "accident" that we believe is relevant are differences in land endowments across village small groups at the outset of reform in the early 1980s.
} 
subsequent growth. Through the lens of the 2SLS framework, if this taste is exogenous to the growth equation, we can view it as a potentially exogenous shifter of initial income inequality, leading to a different growth trajectory. ${ }^{23}$ On the other hand, the importance of collective ownership may reflect unobserved heterogeneity $\left(\theta_{v}\right)$, in which case the above interpretation is wrong: it is $\theta_{v}$ that drives growth, not initial income inequality. In order to address this possibility, we need to move beyond instrumental variables, and exploit the panel dimension of the village data. To this point, our intermediate conclusion is there is evidence linking initial inequality to subsequent growth of household income, which is neither an artifact of aggregation or measurement error.

\subsection{Panel Data Results}

The simplest way to control for $\theta_{v}$, and its potential confounding of the correlation between income, land, and asset inequality, is through the Fixed Effect (FE) specification. However, it is also worth interpreting the panel results through the first difference (FD) estimator:

$$
\Delta \ln y_{v t}=\gamma_{1} \Delta \ln y_{v t-1}+\gamma_{2} \Delta X_{v t-1}+\beta_{v} \Delta G_{v t-1}+v_{v t}
$$

This transformation of equation (4) underscores the re-framing of the question entailed by moving to the panel: If the level of inequality is bad for growth, then increases of inequality should also reduce subsequent growth, mediated by the same $\beta_{v}$. The FD specification purges $G_{v t-1}$ and $\Delta \ln y_{v t}$ of any correlation driven by initial village conditions and their long run growth path. Even if most of the linkage is at long-run frequencies, we should obtain the same estimates of $\beta_{v}$ as long as equation (3) is correct.

We construct a panel version of the cross-section data, comprised of four time periods, taking three-year village averages of the underlying annual data. ${ }^{24}$ This step is especially important in the panel, as FE estimation will highlight high frequency variation in the data that may be dominated by noise (especially measurement error). Measured inequality, for example, might fluctuate around a slow moving trend, either because of genuine variation, or year-to-year measurement error. Three-year averages dampen some of the non-genuine changes in variables like the Gini. As we saw in the cross-section, measurement error reduces the empirical links

\footnotetext{
${ }^{23}$ As we discuss later, this result is not due to the presence of township and village enterprises (TVEs).

${ }^{24}$ The four time periods are 1986-87-88; 1989-90-91; 1993, 95-96; 1997-98-99.
} 
between inequality and growth, and we require similar IV strategies to address measurement error in the panel.

The panel results are presented in Table 6. There are four "packages" of estimates: No instruments ("OLS"), and three instrumental variables (2SLS) versions with similar instrument sets to those used in Table 4 (measurement error-inspired; "lean" land; and "fat"). The 2SLS estimators serve two purposes: first, they help address measurement errors, and second, they deal with the potential correlation between the lagged dependent variable (in this case, lagged income) and the FE or FD error term. ${ }^{25}$ For each "package," we report the FE results for a balanced panel of villages, with the Random Effects (RE) results only reported for the "OLS" package.

Across all specifications, there is one robust finding: Changes of inequality do not affect the growth trajectory of a village. ${ }^{26}$ Furthermore, because we use measurement-error robust instruments in columns (4) to (9), we are confident that the insignificance is not an artifact of measurement error. The specification test in the "OLS" package suggests that the RE estimator is rejected in favour of the FE estimator - though the coefficients on the Gini are essentially the same. Testing between the OLS-FE and various 2SLS specifications, there is no evidence against the null hypothesis that OLS-FE is the preferred specificaton. In any event, we obtain the same answer in all specifications: there is no evidence of link between inequality and growth once we control for the unobserved $\theta_{v}$.

A potential explanation for this finding is simultaneity bias, whereby the dominant link between the two variables is causality running from growth to inequality: as villages grow, inequality rises as a by-product of development (e.g., Kuznets (1955); Anand and Kanbur (1993); Lundberg and Squire (2003)). Our IV strategy should mitigate this possibility, insofar as rising land inequality is not driven by growth. To explore the possibility, we estimated reverse-variants of the growth regressions to see whether there was any evidence of a Kuznets-like process. We do not show them, but our results mimic those reported in Table 6: we found no evidence of an empirical link between growth and inequality in the panel. ${ }^{27}$

Do the panel results imply that inequality doesn't matter, and that the cross-section results are spurious? No. They imply that whatever factor is at play, whether the unobservable, $\theta_{v}$, or genuine differences in a variable highly correlated with it, e.g., inequality, the inequality-

\footnotetext{
25 See Arellano and Bond (1991); Anderson and Hsiao (1982)

26 The elimination, or the attenuation, of the cross-section inequality-growth relationship in the panel specification is a common finding. For example, see Barro (2000), Forbes (2000), and Panizza (2003).

27 Another possibility, noted by Banerjee and Duflo (2003) in their evaluation of Forbes (2000), is a nonlinear (quadratic) effect of changes in inequality on subsequent growth. We also explored this possibility, adding quadratic terms to our panel growth equation, and still found the Gini to be insignificant.
} 
growth relationship holds only in the low frequency, long run data. The panel does, however, provide some insight on the nature of these connections. As with the household-level data, it points away from a simple capital or credit-market based story. With this class of explanations, we would expect that inequality mattered in the short run. Instead, our results further point to an institutionally-oriented explanation. Whether the unobserved institutions are caused by, or just correlated with $\theta_{v}$, is unresolved. A second implication of our findings is that whatever legitimate concerns may exist over rising inequality in China, there is no evidence in our data to suggest that rising inequality "chokes" growth.

\subsection{Exploring the Nature of $G_{v, t-1}\left(\operatorname{or} \theta_{v}\right)$}

Whether it is $G_{v, t-1}$, or the highly correlated $\theta_{v}$, that is negatively related to long run growth, what more can we learn about the channels by which the village income distribution affects household income growth? We now turn to a series of explorations that may inform us about other patterns linking inequality (or $\theta_{v}$ ) to growth. An organizing question is which class of explanations - credit-market or public goods - is most likely behind $\beta_{v}$

\subsection{Inequality and Economic Structure}

To start, we explore the relationship between inequality and other indicators of "economic development." Specifically, in Table 7 we disaggregate household income to see which income components are most adversely affected by inequality. The regressions are slight variations of the cross-section specifications in Table 4:

$$
\Delta \ln y_{v t}^{T y p e}=\alpha_{0}^{T y p e}+\alpha_{1}^{T y p e} \ln y_{v t-1}^{T y p e}+\alpha_{2}^{T y p e} X_{v t-1}+\beta_{v}^{T y p e} G_{v t-1}++u_{v t}^{\text {Yype }}
$$

The principal difference is that we control for initial income of the particular type, $\ln y_{v t-1}^{T y p e}$. Inequality is still measured by the Gini for total income. We estimate the regressions by OLS and 2SLS, employing the same sets of instruments ("lean land," and "extended"), and the same controls (i.e., province fixed effects and other location-specific variables).

In the first two pairs of columns we break income into "Agricultural" (Crop) and "Nonagricultural" components. One way that inequality could affect economic growth is through credit market imperfections. For example, if retained earnings are the only way to finance investment in family businesses or off-farm activity, and assuming that there are minimum thresholds for such 
investments, then for a given level of average income we would expect greater investment (and thus growth) in more equal villages. Column (1) shows the OLS estimates for agricultural income, and in column (2) we report estimates for non-agricultural income. The contrast is fairly stark: Inequality is positively (but insignificantly) related to agricultural growth; however, nonfarm income growth is negatively related to initial inequality. This suggests that inequality affects growth through its effect on the composition of economic activity, and the ability of households to move into more rapidly growing sources of income. Interestingly, low inequality has a similar effect to higher education: Higher initial education is strongly correlated with non-agricultural development.

In the next two columns we disaggregate non-agricultural income into two main components: (1) Wage income (including wage income for household members working outside the village); and (2) Family-run business income. Statistically, the effect of inequality seems stronger for wage income than family businesses. Given the important role of education in accessing off-farm jobs (as is clear in column 3), this result suggests that the "public good," or an education-based explanation may link inequality to growth. Credit may yet be necessary for households to finance off-farm employment (including migration) through "retained earnings." However, if credit were the key consideration, inequality should matter more in the family-run business equation.

Columns (5) through (12) repeat the analysis using instrumental variables for initial income and inequality (using the same instrument sets). As in previous tables, the 2SLS estimators satisfy the conventional specification tests concerning the fit of the first stage, and over-identification tests. They also yield results similar to OLS: Lower inequality in 1986 is correlated with greater village economic development outside agriculture, especially for wage income.

\subsection{The role of Township and Village Enterprises (TVEs)}

One possible institutional explanation, and candidate $\theta_{v}$, is that the low-inequality villages had better developed non-farm sectors at the beginning, and in particular, had collectively-owned township and village enterprises that either flourished themselves, or fostered the growth of a complementary non-farm sector. We noted in Table 5, that in the reduced form inequality and growth equations, village ownership of assets was negatively correlated with inequality, and weakly positively correlated with subsequent growth. Perhaps these assets reflect the beneficial impact of TVEs. 
To more precisely evaluate this possibility, we gleaned village-level information on the presence of TVEs. There is no perfect measure of the extent of TVEs at the beginning of the sample; however, we use the 1993 survey to measure the existence of the TVEs in 1993. To capture the first order cross-village variation in TVEs, we construct a TVE variable equal to the number of TVEs. Table 8 reports results of our standard village-level regressions, including the TVE variable. We report the results for the level and composition of income (i.e., agricultural and non-agricultural). As before, we report OLS and 2SLS specifications, using the lean land, and "fat" instrument sets. The "fat" instrument set includes the village collective asset variable, so we also report the impact of including TVEs on the significance of this variable in the reduced form. The short summary of our results is that controls for the number of TVEs have no impact on our previous conclusions. If TVEs - or even the propensity to have them - were correlated with the unobservable $\theta_{v}$, we would expect a reduction in coefficients on the Gini. But inequality remains just as important a predictor of growth and development, while the TVE variables are themselves statistically insignificant. The coefficient signs are what we might expect: TVEs are positively, though insignificantly, related to growth of incomes, especially non-farm incomes. Finally, the TVE measures do not diminish the importance of the "share of assets owned by the collective" in the reduced form equation for the Gini. TVEs do not appear to be an important part of the story.

\subsection{Does Inequality Hurt the Poor More than the Rich?}

Are the rich immune to the deleterious effect of high inequality? If a household is rich in a high inequality village, it may be less adversely affected by imperfect credit markets - and may even have an advantage. On the other hand, if the inequality-growth mechanism is primarily related to public goods (like schools) there may be no reason to expect a differential distribution of the benefits of low inequality. Perhaps the poor will benefit more from public goods? To address this question we return to the household-level specification, adding an interaction term between initial household income and the initial level of inequality. If the poor are hurt more by high inequality, we expect the interaction effect to be positive, with higher incomes mitigating the the adverse impact of inequality. Results of this exercise are presented in Table 9.

In column 1 we reproduce the basic OLS household level specification (identical to Table 3, Column 1), showing the overall negative impact of inequality. The interaction effect is added in Column (2), and is negative, but statistically insignificant. The negative sign is consistent with the rich being most adversely affected by inequality (not the poor). The sign, however, is less notable than the insignificance of the coefficient. Measurement error is a probably a greater possibility at the household level, especially given the key variable is the interaction between 
initial household income and the village Gini. For this reason we reproduce the exercise using an expanded set of instruments that includes the original village-level "lean land" and "extended" instruments, adding household-level instruments (based on wage income, and income from family businesses). This is a tall order for the IV exercise. The specification tests suggest we do a reasonable job in the first stage regressions, though less well in satisfying the overidentification restrictions (which are rejected). That said, the 2SLS results are similar to OLS: there appears to be no significant interaction between initial household income and the level of inequality in the village. To the extent that we expect such a relationship when contemporaneous credit shortages are a concern, this evidence also points towards the class of explanations based on local public goods (or taxes).

\subsection{Other Measures of Public Expenditure and Taxation}

The "public good" class of explanations suggests that lower inequality leads to collective choices that are better for long run growth. The mechanism might be lower or less punitive (redistributive) taxes, or the collective decision to invest in public goods or higher education that benefits most villagers. The RCRE data has a limited number of "public finance" and collective choice variables that we can investigate. None of these variables turns out to be the elusive $\theta_{v}$, whose inclusion in our growth regression "explains away" the impact of inequality on growth. However, to the extent that our evidence points towards this class of explanations, it would be more convincing to find some of the observable channels by which inequality affects village governance. So far, we have highlighted the potential role of education, insofar as low inequality has a similar effect on growth as higher education. But education itself is unlikely the only factor, since we already control for education in the growth regression, and inequality is highly significant. Furthermore, as we saw in the reduced form reported in Table 5, education is insignificantly correlated with the village Gini. Unobserved school quality is one candidate for the important village investment that behaves like the quantity of education, without being fully controlled by the level. ${ }^{28}$

28 Fan, Zhang, and Zhang (2004) catalogue other potential provincial-level public investments that are correlated with growth and poverty reduction in rural China, including: agricultural R and D; irrigation; rural education; and infrastructure (roads, electricity, and telecommunications). 
Our explorations are restricted to the limited set of observables in the RCRE surveys. We constructed a variety of public finance variables from both the taxation and expenditure side of the village books. Our base regression is a variant of our cross-section growth equation:

$$
\tau_{v t-1}=\gamma_{0}+\gamma_{1} \ln y_{v t-1}+\gamma_{2} X_{v t-1}+\gamma_{3} G_{v t-1}+u_{v t}
$$

where $\tau_{v t-1}$ is a measure of public finances at the beginning of the sample period. We focus on whether there are observable choices made by village governments that are correlated with initial inequality, i.e., we are interested in $\gamma_{3}$ for the various public finance measures. A separate, and more difficult, question is whether these choices ultimately help or hinder growth.

Tables 10 and 11 report representative findings from these explorations. For each dependent variable, we show the OLS and 2SLS coefficients, employing the same instruments as in other exercises. The public finance variables we present are listed below, with details provided in the Appendix (Section 8.0):

- Village Revenue per Capita (log): Do more equal villages establish a tax regime that permits the collection of greater tax revenues that can be used to support public investments? Village revenue includes income from collectively owned assets, like TVEs.

- Village Expenditure per Capita (log): Do more equal villages spend more, presumably in the provision of public goods that may enhance growth?

- Village Taxes and Fees per capita: This is similar to the village revenue measure, except that it only includes taxes and fees.

- Village Average Tax Rate: Do more equal villages adopt lower, and less punitive tax rates, that could encourage growth?

- Progressivity of village taxes: Do more equal villages set "fairer" taxes? We measure tax progressivity as the ratio of the (actual) tax rate of the richest $25 \%$ of villagers to the poorest $25 \%$ of villages. In more "progressive" villages, this ratio should be higher.

In the first panel of Table 10, we show results for village revenue. Not surprisingly, we find that revenue per capita is higher in richer villages, and lower in villages that are most engaged in farming. While we find that high inequality villages have less revenue per capita, in accordance with expectations that low inequality may be related to a greater ability to collect tax revenue from a broad base, the coefficient is statistically insignificant. In the last three columns of Table 10, we show the coefficients for expenditure per capita. Not surprisingly, these results mirror those for revenue; in particular, there is no statistically significant link between initial inequality and the overall level of public spending or taxation (though the sign is "correct"). In 
the first three columns of Table 11, we break out the tax and fee components of village revenue. Once non-tax revenue is subtracted from total revenue, we observe that taxes are actually higher in more agricultural villages. They are also slightly higher in more unequal villages, though the result is insignificant. These results thus suggest that there is no empirical link between initial inequality and the "tax base" of villages.

In the last two sets of specifications we explore the links between inequality and tax rates. In columns (4) through (6) we see weak evidence that tax rates are higher in more unequal villages. Richer villages also have lower tax rates, while villages with a greater share of activity in farming also have higher average taxes. The only statistically significant link between inequality and the public finance variables occurs with the degree of tax progressivity in the village. When we use measurement error-inspired instruments (column 8), we find that higher inequality is associated with a lower degree of progressivity (i.e., flatter taxes), a finding similar to that of Sokoloff and Zolt (2005). Taken at face value, this suggests that in villages where there is lower inequality, or possibly greater social cohesion, taxes are more progressive: higher income households pay a larger share of income in taxes. It isn't clear that this tax rate would then feed into growth, with progressive taxes fostering growth. Instead, it may be a separate indicator that low inequality villages are more egalitarian in their selection of policies, including tax policy. These egalitarian policies, insofar as they may also lead to greater investment in public goods such as schools, may contribute to growth. It is not clear whether progressive taxes are just another reflection of the egalitarian streak $\left(\theta_{v}\right)$, or whether they, too, are caused by low initial inequality. It is also unclear whether or not more progressive taxes are correlated with growth enhancing policies. But ignoring the standard errors, our results suggest that high inequality is associated with higher overall tax rates, with more of the tax burden falling on low and middle income villagers. It isn't difficult to imagine scenarios by which this hurts growth. As a final note, we explored several other public finance variables besides the ones reported here: they yielded the same basic pattern of insignificance.

\subsection{Conclusions}

Is the trajectory of household income growth adversely affected by the level of inequality in the village in which it lives? The leading explanations that have been proposed for an economy-wide linkage between inequality and growth - poorly developed factor markets, lower provision of public goods, or growth-inhibiting forms of taxation - may operate in principle at the village-level in rural China. In rural China, especially from the beginning of economic reforms, local governments, their policies, and local economic conditions were important dimensions of 
the economic environment in which households developed. Using a rich household-level data set stratified by village, we estimate the empirical links between the level of inequality near the beginning of reforms (1986) and the growth of household incomes in the village through 1999. Whether we use the sample of households that can be tracked all the way through the panel, or treat the villages as distinct cross-sections, we find robust evidence that initial inequality is significantly related to subsequent growth: Inequality "hurts" growth. Because we can estimate the relationship at the household level, and given a rich set of instruments that can be used to address measurement error, we are able to rule out a number of explanations. In particular, we can rule out the possibility that the relationship is an artifact of aggregation, measurement error, or other mechanical explanations based on non-linearities linking initial household income to growth. Furthermore, since we control for own resources in the household-level specification, we cast doubt on the imperfect credit-market class of explanations. In short, we find robust evidence that high village inequality exerts a negative "externality" on household economic growth.

We cannot rule out, however, that there is an unobserved "third" factor that is correlated with both initial inequality and subsequent growth. Indeed, when we employ a village fixedeffects specification to address this concern, the link between inequality and growth vanishes. However, it is also possible that the short-run links between inequality and growth are weak, and that whatever process drives growth, operates at longer run frequencies in the data. The village fixed-effects estimator would likely discard this important (and only) part of the relationship between inequality and growth.

To better understand why high inequality might hurt growth, we explore the other aspects of the growth experience of the village, and potential linkages to various initial conditions, especially in terms of public finance (revenue and expenditure). First, we find that the primary nature of the growth-inequality linkage operates through the composition of economic activity: low inequality seems to enhance growth in non-farm incomes, and tilts the village away from agriculture. Second, we find weak support for the influence of inequality through local political economy channels: Higher inequality is associated with higher overall tax rates; more regressive taxes; and lower levels of revenue and expenditures. These patterns are consistent with low inequality leading to greater investments in growth-enhancing public goods or the setting of "fairer" taxes that also foster growth, echoing the recent suggestions of Sokoloff and Zolt (2005). Even without fully understanding the mechanism, which remains unobserved, it appears that whether it is genuinely exogenous higher inequality, or an unobservable factor that is correlated with it, villages with higher inequality grow significantly more slowly. 


\subsection{Appendix: Definitions of Public Finance Variables}

1. Village Revenue Per Capita: the weighted average revenue per capita from the village for the 1986 to 1988 period and calculated from the village survey. We first calculate the three-year sum of village revenue in 1986 Yuan RMB, and then divide by the three year sum of village population. In our estimation, we use the log of this value.

2. Village Expenditure Per Capita: the weighted average expenditure per capita from the village for the 1986 to 1988 period and calculated from the village survey. We first calculate the three-year sum of village expenditure in 1986 Yuan RMB, and then divide by the three year sum of village population. In our estimation, we use the log of this value.

3. Village Taxes and Fees per Capita: We calculate this in the same manner as village revenue per capita. It is calculated from the village survey, but excludes revenues from TVEs, other revenues and an unobserved residual.

4. Village Average Tax Rate: the weighted average tax rate faced by households in the village. We first add the taxes and fees paid over the three-year period for all households enumerated in the household survey, and then we divide by total income earned by these households over the three-year period.

5. Progressivity of village taxes: using the method in (4) above, we calculate the three-year weighted average tax rate faced by richest quartile of households and divide by the three-year weighted average tax rate faced by the poorest quartile. An increase in this index reflects an increase in tax progressivity. 


\subsection{References}

Acemoglu, Daron. 1996. "A Microfoundation for Social Increasing Returns in Human Capital Accumulation." Quarterly Journal of Economics, 111:3, pp. 779-804.

Aghion, Philippe, Eve Caroli, and Cecilia Garcia-Penalosaand. 1999. "Inequality and Economic Growth: The Perspective of the New Growth Theories." Journal of Economic Literature, 37:4, pp. 1615-60.

Alesina, Alberto and Eliana La Ferrara. 2000. "Participation in Heterogeneous Communities." Quarterly Journal of Economics, 115:3, pp. 847-904.

Alesina, Alberto and Dani Rodrik. 1994. "Distributive Politics and Economic Growth." Quarterly Journal of Economics, 109:2, pp. 465-90.

Anand, S. and Ravi Kanbur. 1993. "The Kuznets Process and the Inequality-Development Relationship." Journal of Development Economics, 40, pp. 25-52.

Anderson, T W and Cheng Hsiao. 1982. "Formulation and Estimation of Dynamic Models Using Panel Data." Journal of Econometrics, 18:1, pp. 47-82.

Arellano, Manuel and Stephen Bond. 1991. "Some Tests of Specification for Panel Data: Monte Carlo Evidence and an Application to Employment Equations." Review of Economic Studies, 58:2, pp. 277-97.

Banerjee, Abhijit and Esther Duflo. 2003. "Inequality and Growth: What Can the Data Say?" Journal of Economic Growth, 8, pp. 267-99.

Banerjee, Abhijit, Paul Gertler, and Maitreesh Ghatak. 2002. "Empowerment and Efficiency: Tenancy Reform in West Bengal." Journal of Political Economy, 110:2, pp. 239-80.

Banerjee, Abhijit and Lakshmi Iyer. 2005. "History, Institutions, and Economic Performance: The Legacy of Colonial Land Tenure Systems in India." American Economic Review, 95:4, pp. 1190-213.

Banerjee, Abhijit, Dilip Mookherjee, Kaivan Munshi, and Debraj Ray. 2001. "Inequality, Control Rights, and Rent Seeking: Sugar Cooperatives in Maharashtra." Journal of Political Economy, 109:1, pp. 138-90.

Banerjee, Abhijit and andrew Newman. 1993. "Occupational Choice and the Process of Development." Journal of Political Economy, 101:2, pp. 274-98.

Bardhan, Pranab, Maitreesh Ghatak, and Alexander Karaivanov. 2006. "Wealth Inequality and Collective Action." Department of Economics, London School of Economics, mimeograph.

Barro, Robert J. 2000. "Inequality and Growth in a Panel of Countries." Journal of Economic Growth, 5, pp. 5-32.

Benabou, Roland. 1996a. "Heterogeneity, Stratification and Growth: Macroeconomic Implications of Community Structure and School Finance." American Economic Review, 86:3, pp. 584-609.

Benabou, Roland. 1996b. "Inequality and Growth," in NBER Macroeconomics Annual. Ben S. Bernanke and Julio Rotemberg eds. Cambridge, MA: MIT Press, pp. 11-74.

Benjamin, Dwayne, Loren Brandt, and John Giles. 2005. "The Evolution of Income Inequality in Rural China." Economic Development and Cultural Change, 53:4, pp. 769-824.

Benjamin, Dwayne, Loren Brandt, John Giles, and Sangui Wang. 2005. "Income Inequality During China's Economic Transition," in China's Great Transformation (forthcoming). Loren Brandt and Thomas Rawski eds.

Besley, Timothy and Robin Burgess. 2000. "Land Reform, Poverty Reduction, and Growth: Evidence from India." Quarterly Journal of Economics, 115:2, pp. 389-430.

Brandt, Loren, Scott Rozelle, and Linxiu Zhang. 2005. "Tax-for-Fee Reform,Village Operating Budgets and Public Goods Investment." World Bank, Beijing Office. 
Buck, Pearl S. 1933. All Men are Brothers (translation of Shi and Luo, Shui Hu Huan [The Water Margin]). New York: J. Day Co.

Dayton-Johnson, Jeff. 2000. "Determinants of Collective Action on the Local Commons: A Model with Evidence from Mexico." Journal of Development Economics, 62:1, pp. 181208.

Dayton-Johnson, Jeff and Pranab Bardhan. 2002. "Inequality and Conservation of the Local Commons: A Theoretical Exercise." Economic Journal, 112:481, pp. 577-602.

Deaton, Angus. 2003. "Health, Inequality, and Economic Development." Journal of Economic Literature, 41:1, pp. 113-58.

Easterly, William. 2005. "Inequality does cause underdevelopment." Center for Global Development, Working Paper \#1.

Fan, Shenggen, Linxiu Zhang, and Xiaobo Zhang. 2004. "Reforms, Investment, and Poverty in Rural China." Economic Development and Cultural Change, 52:2, pp. 395-421.

Forbes, Kristin. 2000. "A reassessment of the relationship between inequality and growth." American Economic Review, 90:4, pp. 869-87.

Glaeser, Edward. 2005. "Inequality." NBER Working Paper, \#11511.

Hutzler, Charles. 2003. "For China's Poor Regions, a Kinder, Gentler Beijing --- Incoming Leadership Makes A Priority of Those Ignored By Headlong Liberalization." The Wall Street Journal, 25 February 2003 ed.: A13.

Kaldor, Nicholas. 1956. "Alternative Theories of Distribution." Review of Economic Studies, 23:2, pp. 83-100.

Kaldor, Nicholas. 1957. "A Model of Economic Growth." Economic Journal, 67, pp. 591-624.

Kuznets, Simon. 1955. "Economic growth and income inequality." American Economic Review, 45:1, pp. 1-28.

Kwaja, Asim. 2004. "Can Good Projects Succeed in Bad Communities?" Kennedy School of Government, Harvard University, mimeograph.

Lloyd-Ellis, Huw. 2000. "Public Education, Occupational Choice and the Growth-Inequality Relationship." International Economic Review, 41:1, pp. 171-201.

Lloyd-Ellis, Huw. 2003. "On the Impact of Inequality on Productivity Growth in the Short and Long Term: A Synthesis." Canadian Public Policy, XXIX:Supplement, pp. S65-S86.

Lundberg, Mattias and Lyn Squire. 2003. "The simultaneous evolution of growth and inequality." Economic Journal, 113, pp. 326-44.

Panizza, Ugo. 2002. "Income Inequality and Economic Growth: Evidence from American Data." Journal of Economic Growth, 7, pp. 25-41.

Persson, Torsten and Guido Tabellini. 1994. "Is Inequality Harmful for Growth?" American Economic Review, 84:3, pp. 600-21.

Putterman, Louis. 1993. Continuity and Change and China's Rural Development. New York: Oxford University Press.

Ravallion, Martin. 1998. "Does Aggregation Hide the Harmful Effects of Inequality on Growth?" Economics Letters, 61:1, pp. 73-77.

Ravallion, Martin and Shaohua Chen. 1999. "When Economic Reform Is Faster Than Statistical Reform: Measuring and Explaining Income Inequality in Rural China." Oxford Bulletin of Economics and Statistics, 61:1, pp. 33-56.

Ravallion, Martin and Shaohua Chen. 2005. "China's (Uneven) Progress Against Poverty." Journal of Development Economics (in press).

Shapiro, Sydney. 1981. Outlaws of the Marsh (translation of Shi and Luo, Shui Hun Huan [The Water Margin]). Beijing (Foreign Languages Press) and Bloomington: Indiana University Press.

Shi, Nai'an and Luo Guanzhong. 1365c. Shui Hun Huan [The Water Margin]: (see Buck, 1933, and Shapiro, 1981, among other translations). 
Sokoloff, Kenneth and Eric Zolt. 2005. "Inequality and the Evolution of Institutions of Taxation: Evidence from the Historical Experience of the Americas." mimeograph, Department of Economics, UCLA.

Stiglitz, Joseph. 1969. "The Distribution of Income and Wealth among Individuals." Econometrica, 37:3, pp. 382-97.

United Nations Development Program (Beijing Office). 2005. "The China Human Development Report."

World Bank. 2003. "China: Promoting Growth with Equity." Country Economic Memorandum, Poverty Reduction and Economic Management Unit, East Asia and Pacific Region, Report No. 24169-CHA. 
Table 1

Household-Level Descriptive Statistics

The Composition of Income in 1987 Compared to 1999

(in $1986 \mathrm{RMB}$ )

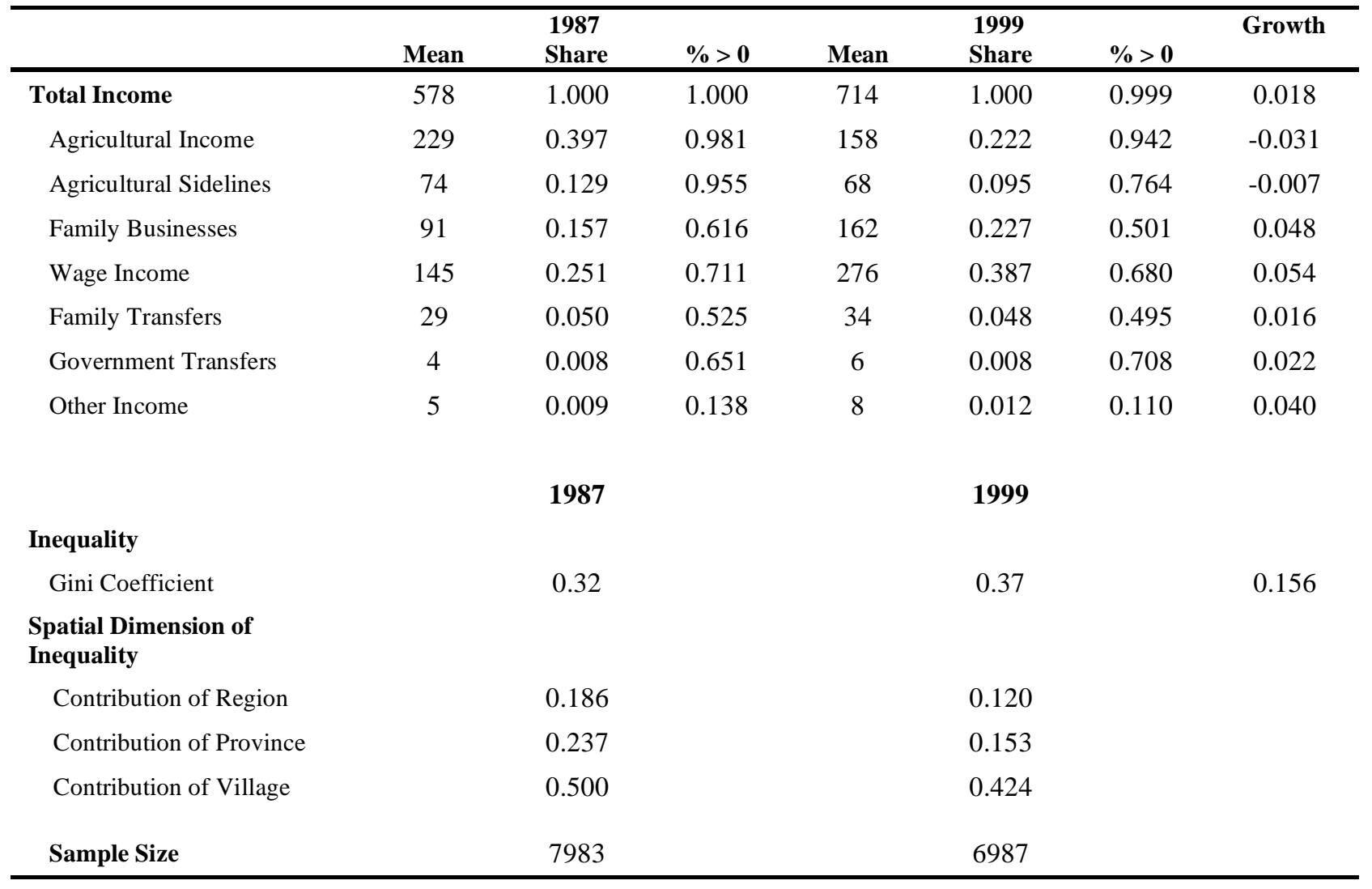

Notes: This table compares the composition of income in 1987 to 1999 . Real per capita income is shown for detailed subcategories of income, along with the share of income ("Share") accounted for, and the proportion of households with non-zero income for that source. The last column reports the implied annual growth rate of income for that source. Note that wage income is divided between "Local" wage income, "Temporary Migrant" and employment in the local government. Temporary migrant employment includes both commuters returning home on weekends and longer-term temporary migrants, and in most cases involves employment outside of the township. 
Table 2

Summary of Village Characteristics at Start of Period

\begin{tabular}{|c|c|c|c|}
\hline & \multicolumn{3}{|c|}{$\begin{array}{l}\text { Village Averages for the Initial Period } \\
(1986-87-88)\end{array}$} \\
\hline & $25^{\text {th }}$ & Median & 75 th \\
\hline \multicolumn{4}{|l|}{ Income } \\
\hline Income Per Capita & 340 & 496 & 636 \\
\hline Growth Rate of Per Capita Income (Period 1 to 4) & 0.001 & 0.027 & 0.049 \\
\hline Gini (Income Per Capita) & 0.190 & 0.219 & 0.266 \\
\hline$\Delta$ Gini (Income Per Capita) from Period 1 to 4 & -0.002 & 0.041 & 0.076 \\
\hline \multicolumn{4}{|l|}{ Covariates } \\
\hline Education (Years Per Adult) & 4.679 & 5.779 & 6.411 \\
\hline Crop Income Share & 0.354 & 0.475 & 0.606 \\
\hline \multicolumn{4}{|l|}{ Potential Instruments } \\
\hline Consumption Per Capita & 299 & 398 & 485 \\
\hline Growth Rate of Per Capita Consumption (Period 1 to 4) & 0.002 & 0.022 & 0.037 \\
\hline Gini (Consumption Per Capita & 0.148 & 0.168 & 0.183 \\
\hline$\Delta$ Gini (Consumption Per Capita) from Period 1 to 4 & 0.014 & 0.033 & 0.062 \\
\hline Ln(Average Off-Farm Wage Income) & 3.658 & 4.248 & 4.766 \\
\hline Ninety /Ten Income Ratio & 2.329 & 2.707 & 3.239 \\
\hline Seventy-Five/Twenty-Five Income Ratio & 1.499 & 1.517 & 1.538 \\
\hline Crop Land Per Capita & 0.924 & 1.283 & 2.074 \\
\hline Other Land Per Capita & 0.081 & 0.364 & 3.068 \\
\hline Village Average Dependency Rate & 0.403 & 0.435 & 0.473 \\
\hline Gini (Cultivated Land Per Capita) & 0.140 & 0.171 & 0.210 \\
\hline Coefficient of Variation of Household Dependency Rates & 0.362 & 0.434 & 0.498 \\
\hline Ln(Household Per Capita Productive Assets) & 5.036 & 5.554 & 6.198 \\
\hline Proportion of Assets Owned by Collective & 0.101 & 0.249 & 0.415 \\
\hline Gini (Household Productive Asset Per Capita) & 0.387 & 0.506 & 0.641 \\
\hline Share of $\mathrm{HH}$ with Other Land & 0.016 & 0.094 & 0.683 \\
\hline (Other Land PC)*(Share of HH with Other Land) & 0.001 & 0.027 & 1.137 \\
\hline Share of Crop Land Managed by Collective & 0.000 & 0.000 & 0.025 \\
\hline Share of Other Land Managed by Collective & 0.200 & 0.614 & 1.000 \\
\hline Village Location & Mean & $\begin{array}{l}\text { Standard } \\
\text { Deviation }\end{array}$ & \\
\hline Village Near a City & 0.053 & 0.224 & \\
\hline Village in the Hills & 0.377 & 0.486 & \\
\hline Village in the Mountains & 0.243 & 0.432 & \\
\hline
\end{tabular}

Notes: These are village level summary statistics for the 100 villages used in our analyses. We present information on the initial 1986 to 1988 base period used in our cross-section analyses. 
Table 3

\section{The Correlation Between Local Inequality and Subsequent Growth at the Household and Village Level}

\begin{tabular}{|c|c|c|c|c|c|c|}
\hline \multirow[b]{2}{*}{ Model } & \multicolumn{2}{|c|}{$\begin{array}{l}\text { Dependent Variable: } \\
\Delta \ln (\text { hh inc pc })\end{array}$} & \multicolumn{4}{|c|}{$\begin{array}{c}\text { Dependent Variable: } \\
\Delta \ln (\text { village avg inc pc) }\end{array}$} \\
\hline & $\begin{array}{c}(1) \\
\text { Panel } \\
\text { HHs }\end{array}$ & $\begin{array}{c}(2) \\
\text { Panel } \\
\text { HHs }\end{array}$ & $\begin{array}{c}(3) \\
\text { Panel } \\
\text { HHs }\end{array}$ & $\begin{array}{c}(4) \\
\text { Full } \\
\text { Sample }\end{array}$ & $\begin{array}{c}\text { (5) } \\
\text { Full } \\
\text { Sample }\end{array}$ & $\begin{array}{c}\text { (6) } \\
\text { Full } \\
\text { Sample }\end{array}$ \\
\hline Gini (Income Per Capita) & $\begin{array}{l}-0.102 * \\
(0.045)\end{array}$ & $\begin{array}{l}-0.112 * \\
(0.046)\end{array}$ & $\begin{array}{l}-0.071 \\
(0.055)\end{array}$ & $\begin{array}{l}-0.071 \\
(0.045)\end{array}$ & $\begin{array}{l}-0.065 \\
(0.046)\end{array}$ & $\begin{array}{l}-0.068 \\
(0.044)\end{array}$ \\
\hline $\begin{array}{l}\text { ln(Village Average Income } \\
\text { Per Capita) }\end{array}$ & $\begin{array}{l}0.021 * \\
(0.007)\end{array}$ & $\begin{array}{l}0.019 * \\
(0.007)\end{array}$ & $\begin{array}{l}-0.046^{*} \\
(0.008)\end{array}$ & $\begin{array}{l}-0.048^{*} \\
(0.007)\end{array}$ & $\begin{array}{l}-0.048 * \\
(0.007)\end{array}$ & $\begin{array}{l}-0.048 * \\
(0.007)\end{array}$ \\
\hline $\begin{array}{l}\ln (\text { Household Income Per } \\
\text { Capita) }\end{array}$ & $\begin{array}{l}-0.075^{*} \\
(0.003)\end{array}$ & $\begin{array}{l}-0.554 * \\
(0.154)\end{array}$ & $\begin{array}{l}- \\
-\end{array}$ & - & - & - \\
\hline $\begin{array}{l}(\ln (\mathrm{HH} \text { Income Per } \\
\text { Capita }))^{\wedge} 2\end{array}$ & - & $\begin{array}{l}0.075^{*} \\
(0.027)\end{array}$ & - & - & - & - \\
\hline $\begin{array}{l}(\ln (\mathrm{HH} \text { Income Per } \\
\text { Capita }))^{\wedge} 3\end{array}$ & - & $\begin{array}{l}-0.004 * \\
(0.002)\end{array}$ & $\begin{array}{l}- \\
-\end{array}$ & $\begin{array}{l}- \\
-\end{array}$ & $\begin{array}{l}- \\
-\end{array}$ & $\begin{array}{l}- \\
-\end{array}$ \\
\hline $\begin{array}{l}\ln (\text { Village Average } \\
\text { Education Per Capita) }\end{array}$ & $\begin{array}{l}0.044 * \\
(0.014)\end{array}$ & $\begin{array}{l}0.045^{*} \\
(0.014)\end{array}$ & $\begin{array}{l}0.046 * \\
(0.013)\end{array}$ & $\begin{array}{l}0.051 * \\
(0.012)\end{array}$ & $\begin{array}{l}0.050 * \\
(0.012)\end{array}$ & $\begin{array}{l}0.051 * \\
(0.012)\end{array}$ \\
\hline $\begin{array}{l}\text { Share of Village Income } \\
\text { From Agriculture }\end{array}$ & $\begin{array}{l}-0.024 \\
(0.015)\end{array}$ & $\begin{array}{l}-0.022 \\
(0.015)\end{array}$ & $\begin{array}{l}-0.026 \\
(0.020)\end{array}$ & $\begin{array}{l}-0.033 \\
(0.017)\end{array}$ & $\begin{array}{l}-0.032 * \\
(0.016)\end{array}$ & $\begin{array}{l}-0.034 * \\
(0.016)\end{array}$ \\
\hline $\begin{array}{l}\text { Average Village Migration } \\
\text { Rate (1986-1999) }\end{array}$ & $\begin{array}{l}- \\
-\end{array}$ & - & $\begin{array}{l}- \\
-\end{array}$ & $\begin{array}{l}- \\
-\end{array}$ & $\begin{array}{c}0.020 \\
(0.046)\end{array}$ & - \\
\hline $\begin{array}{l}\text { Household Attrition Rate } \\
\text { (1986-1999) }\end{array}$ & $\begin{array}{l}- \\
-\end{array}$ & - & - & - & - & $\begin{array}{l}-0.050 \\
(0.100)\end{array}$ \\
\hline $\begin{array}{l}\mathrm{N} \\
\mathrm{r} 2\end{array}$ & $\begin{array}{c}4434 \\
0.4432\end{array}$ & $\begin{array}{l}4434 \\
0.447\end{array}$ & $\begin{array}{c}86 \\
0.5801\end{array}$ & $\begin{array}{c}100 \\
0.5817\end{array}$ & $\begin{array}{c}100 \\
0.5826\end{array}$ & $\begin{array}{c}100 \\
0.5829\end{array}$ \\
\hline $\begin{array}{l}\text { Notes: Household controls (not } \\
\text { household size, household depe } \\
\text { capita, ln(value of household as } \\
\text { households in the panel for the } \\
3 \text { uses only panel households, a } \\
\text { sensitivity of the relationship to } \\
\text { and Model } 6 \text { includes the villag } \\
\text { biased by attrition. All models } \\
\text { whether the village is near a cit } \\
\text { parentheses. An asterisk }(*) \text { inc }\end{array}$ & $\begin{array}{l}\text { own) in Mc } \\
\text { ncy ratio, } \\
\text { s per capita } \\
7 \text { to } 1999 \text { 1 } \\
\text { Model } 4 \text { us } \\
\text { erage share } \\
\text { verage hou } \\
\text { ude provin } \\
n \text { the moun } \\
\text { tes a p-val }\end{array}$ & $\begin{array}{l}\text { ls } 1 \text { and } 2 \\
\text { le share of } \\
\text { Models } 1 \text { ar } \\
\text { iod. Mode } \\
\text { all availabl } \\
\text { village par } \\
\text { old attritio } \\
\text { dummy var } \\
n s \text {, or in th } \\
\text { of less than }\end{array}$ & $\begin{array}{l}\text { le } \ln (\mathrm{HH} \text { a } \\
\text { ng age adu } \\
\text { re househo } \\
\text { rough } 6 \text { ar } \\
\text { seholds in } \\
\text { ting in mis } \\
\text { to examin } \\
\text { and three } \\
\text { Robust, } \\
\text { percent. }\end{array}$ & $\begin{array}{l}\text { age educat } \\
\text {, househol } \\
\text { level regre } \\
\text { stimated at } \\
\text { e village M } \\
\text { nt labor m } \\
\text { he possibili } \\
\text { cation dum } \\
\text { ster correc }\end{array}$ & $\begin{array}{l}\text { n per capit } \\
\text { ultivated } 1 \\
\text { lons using } \\
\text { he village } 1 \\
\text { lel } 5 \text { tests t } \\
\text { ets over th } \\
\text { that the re } \\
\text { y variables } \\
\text { l standard }\end{array}$ & $\begin{array}{l}\text { d per } \\
\text { period, Model } \\
\text { tionship is } \\
\text { or } \\
\text { rors in }\end{array}$ \\
\hline
\end{tabular}


Table 4

The Cross-Sectional Relationship Between Growth and Inequality

Results Using Different Instrument Sets

\begin{tabular}{|c|c|c|c|c|c|c|}
\hline \multicolumn{2}{|l|}{ Model } & $\begin{array}{l}(1) \\
\text { OLS }\end{array}$ & $\begin{array}{l}(2) \\
\text { IV }\end{array}$ & $\begin{array}{l}\text { (3) } \\
\text { IV }\end{array}$ & $\begin{array}{l}\text { (4) } \\
\text { IV }\end{array}$ & $\begin{array}{l}(5) \\
\text { IV }\end{array}$ \\
\hline \multicolumn{2}{|c|}{ Gini (Income Per Capita) } & $\begin{array}{l}-0.0709 \\
(0.0445)\end{array}$ & $\begin{array}{l}-0.1310^{*} \\
(0.0523)\end{array}$ & $\begin{array}{l}-0.2343^{*} \\
(0.1067)\end{array}$ & $\begin{array}{l}-0.2558 \\
(0.1503)\end{array}$ & $\begin{array}{l}-0.2509^{*} \\
(0.0751)\end{array}$ \\
\hline \multicolumn{2}{|c|}{ Ln(Village Income Per Capita) } & $\begin{array}{r}-0.0480^{*} \\
(0.0073)\end{array}$ & $\begin{array}{r}-0.0401 * \\
(0.0123)\end{array}$ & $\begin{array}{l}-0.0430 * \\
(0.0173)\end{array}$ & $\begin{array}{l}-0.0329 \\
(0.0183)\end{array}$ & $\begin{array}{r}-0.0393 * \\
(0.0115)\end{array}$ \\
\hline \multicolumn{2}{|c|}{ Ln(Village Average Ed Per Capita) } & $\begin{array}{l}0.0508^{*} \\
(0.0123)\end{array}$ & $\begin{array}{l}0.0456^{*} \\
(0.0119)\end{array}$ & $\begin{array}{l}0.0430^{*} \\
(0.0142)\end{array}$ & $\begin{array}{l}0.0382 * \\
(0.0176)\end{array}$ & $\begin{array}{l}0.0409^{*} \\
(0.0138)\end{array}$ \\
\hline \multicolumn{2}{|c|}{$\begin{array}{l}\text { Agricultural Income as a Share of Total } \\
\text { Income }\end{array}$} & $\begin{array}{l}-0.0330^{*} \\
(0.0165)\end{array}$ & $\begin{array}{l}-0.0393 \\
(0.0202)\end{array}$ & $\begin{array}{l}-0.0560^{*} \\
(0.0267)\end{array}$ & $\begin{array}{l}-0.0555^{*} \\
(0.0280)\end{array}$ & $\begin{array}{l}-0.0572 * \\
(0.0214)\end{array}$ \\
\hline $\begin{array}{r}\text { Over-Identificat } \\
\text { Chi-Square S } \\
\text { Chi-Probabili }\end{array}$ & $\begin{array}{l}\text { on } \\
\text { atistic } \\
y\end{array}$ & & $\begin{array}{c}0.84 \\
0.360\end{array}$ & $\begin{array}{l}3.35 \\
0.341\end{array}$ & $\begin{array}{c}0.04 \\
0.833\end{array}$ & $\begin{array}{c}4.46 \\
0.924\end{array}$ \\
\hline $\begin{array}{l}\text { The First Stage } \\
\text { Ln(Vill IPC) }\end{array}$ & $\begin{array}{l}\text { F-Test } \\
\text { F-Probability }\end{array}$ & & $\begin{array}{l}10.06 \\
0.000\end{array}$ & $\begin{array}{c}3.88 \\
0.003\end{array}$ & $\begin{array}{c}6.58 \\
0.001\end{array}$ & $\begin{array}{c}3.57 \\
0.000\end{array}$ \\
\hline IPC Gini & $\begin{array}{l}\text { F-Test } \\
\text { F-Probability }\end{array}$ & & $\begin{array}{c}104.32 \\
0.000\end{array}$ & $\begin{array}{c}3.07 \\
0.014\end{array}$ & $\begin{array}{c}4.43 \\
0.006\end{array}$ & $\begin{array}{c}2.48 \\
0.009\end{array}$ \\
\hline $\mathrm{N}$ & & 100 & 100 & 100 & 100 & 100 \\
\hline R2 & & 0.5649 & -- & -- & -- & -- \\
\hline
\end{tabular}

In models 2 through 5, $\ln$ (Village Income Per Capita) and the Gini (Income Per Capita) are treated as endogenous. We use the following instrument sets:

Model 2: Instruments for Measurement Error: Ninety/ten income per capita ratio, seventy-five/twenty-five income per capita ratio, $\ln$ (average wage income per capita).

Model 3: Lean Land Instruments (The Lean Set): Cultivated land gini, cultivated land per capita, other land per capita, village average dependency ratio, coefficient of variation of household dependency ratios.

Model 4: Asset Instruments: Ln(Productive Assets Per Capita), Productive Asset Per Capita Gini, Share of Village Assets Controlled by Collective.

Model 5: Extended Land Instruments and Asset Instruments (The Fat Set): Model 3 and 4 instruments, plus percent of hh other land (forest or fishpond land), percent with other land interacted with other land per capita, share of cultivated land managed by collective, and share of other land managed by the collective.

Notes: All models also include statistically significant province dummy variables and three village location dummy variables (near city, in hills, in mountains). Robust standard errors in parentheses. An asterisk (*) indicates a p-value of less than five percent. 
Table 5

Correlates of Initial Income, Inequality and Village Income Growth

The Reduced Form

\begin{tabular}{|c|c|c|c|c|c|c|c|c|c|}
\hline \multirow{3}{*}{$\begin{array}{l}\text { Model } \\
\text { Variabl } \\
\end{array}$} & \multicolumn{3}{|c|}{ Lean Land Instruments } & \multicolumn{3}{|c|}{ Asset Instruments } & \multicolumn{3}{|c|}{ Fat Instrument Set } \\
\hline & (1) & (2) & (3) & (4) & (5) & (6) & (7) & (8) & (9) \\
\hline & $\ln \left(\mathrm{y}_{1}\right)$ & $\mathrm{G}\left(\mathrm{y}_{1}\right)$ & $\Delta \ln (\mathrm{y})$ & $\ln \left(\mathrm{y}_{1}\right)$ & $\mathrm{G}\left(\mathrm{y}_{1}\right)$ & $\Delta \ln (\mathrm{y})$ & $\ln \left(\mathrm{y}_{1}\right)$ & $\mathrm{G}\left(\mathrm{y}_{1}\right)$ & $\Delta \ln (\mathrm{y})$ \\
\hline $\begin{array}{l}\text { Log Village Average Education Per } \\
\text { Capita }\end{array}$ & $\begin{array}{c}0.306 \\
(0.198)\end{array}$ & $\begin{array}{l}-0.021 \\
(0.027)\end{array}$ & $\begin{array}{l}0.029 * \\
(0.015)\end{array}$ & $\begin{array}{c}0.193 \\
(0.204)\end{array}$ & $\begin{array}{l}-0.018 \\
(0.029)\end{array}$ & $\begin{array}{l}0.034 * \\
(0.015)\end{array}$ & $\begin{array}{c}0.140 \\
(0.206)\end{array}$ & $\begin{array}{l}-0.003 \\
(0.029)\end{array}$ & $\begin{array}{c}0.028 \\
(0.017)\end{array}$ \\
\hline Share of Income From Agriculture & $\begin{array}{l}-0.393 \\
(0.242)\end{array}$ & $\begin{array}{l}-0.158^{*} \\
(0.043)\end{array}$ & $\begin{array}{l}-0.006 \\
(0.022)\end{array}$ & $\begin{array}{l}-0.090 \\
(0.246)\end{array}$ & $\begin{array}{l}-0.134 * \\
(0.040)\end{array}$ & $\begin{array}{l}-0.017 \\
(0.023)\end{array}$ & $\begin{array}{l}-0.104 \\
(0.286)\end{array}$ & $\begin{array}{l}-0.181 * \\
(0.049)\end{array}$ & $\begin{array}{l}-0.016 \\
(0.026)\end{array}$ \\
\hline Arable Land Per Capita Gini & $\begin{array}{l}1.480 * \\
(0.731)\end{array}$ & $\begin{array}{l}0.273 * \\
(0.093)\end{array}$ & $\begin{array}{l}-0.151 * \\
(0.069)\end{array}$ & - & $\begin{array}{l}- \\
-\end{array}$ & $\begin{array}{l}- \\
-\end{array}$ & $\begin{array}{c}1.331 \\
(0.715)\end{array}$ & $\begin{array}{l}0.243 * \\
(0.103)\end{array}$ & $\begin{array}{c}-0.123 \\
(0.072)\end{array}$ \\
\hline Arable Land Per Capita & $\begin{array}{c}0.019 \\
(0.045)\end{array}$ & $\begin{array}{c}0.014 * \\
(0.004)\end{array}$ & $\begin{array}{c}-0.002 \\
(0.003)\end{array}$ & - & - & - & $\begin{array}{c}-0.023 \\
(0.041)\end{array}$ & $\begin{array}{c}0.014 \\
(0.005)\end{array}$ & $\begin{array}{c}0.000 \\
(0.003)\end{array}$ \\
\hline Other Land Per Capita & $\begin{array}{c}-0.010 * \\
(0.002)\end{array}$ & $\begin{array}{c}0.000 \\
(0.001)\end{array}$ & $\begin{array}{c}0.000 \\
(0.000)\end{array}$ & - & - & - & $\begin{array}{l}-0.009 \\
(0.012)\end{array}$ & $\begin{array}{c}0.002 \\
(0.002)\end{array}$ & $\begin{array}{c}0.000 \\
(0.001)\end{array}$ \\
\hline Share of $\mathrm{HH}$ with Other Land & $\begin{array}{l}- \\
-\end{array}$ & - & - & - & - & - & $\begin{array}{c}-0.217 \\
(0.119)\end{array}$ & $\begin{array}{c}-0.006 \\
(0.025)\end{array}$ & $\begin{array}{c}0.018 \\
(0.012)\end{array}$ \\
\hline $\begin{array}{l}\text { (Other LPC }) *(\text { Share of } \mathrm{HH} \text { w/Other } \\
\text { LPC) }\end{array}$ & $\begin{array}{l}- \\
-\end{array}$ & - & $\begin{array}{l}- \\
-\end{array}$ & - & $\begin{array}{l}- \\
-\end{array}$ & - & $\begin{array}{c}0.003 \\
(0.016)\end{array}$ & $\begin{array}{l}-0.002 \\
(0.003)\end{array}$ & $\begin{array}{c}0.000 \\
(0.001)\end{array}$ \\
\hline $\begin{array}{l}\text { Arable Land Under Collective } \\
\text { Management as a Share of Total Land }\end{array}$ & - & $\begin{array}{l}- \\
-\end{array}$ & - & - & - & $\begin{array}{l}- \\
-\end{array}$ & $\begin{array}{c}0.163 \\
(0.134)\end{array}$ & $\begin{array}{l}-0.039 \\
(0.025)\end{array}$ & $\begin{array}{c}0.005 \\
(0.011)\end{array}$ \\
\hline $\begin{array}{l}\text { Other Land Under Collective } \\
\text { Management as a Share of Total Land }\end{array}$ & $\begin{array}{l}- \\
-\end{array}$ & $\begin{array}{l}- \\
-\end{array}$ & - & - & - & $\begin{array}{l}- \\
-\end{array}$ & $\begin{array}{l}-0.066 \\
(0.059)\end{array}$ & $\begin{array}{l}-0.005 \\
(0.010)\end{array}$ & $\begin{array}{c}0.004 \\
(0.006)\end{array}$ \\
\hline $\begin{array}{l}\text { Average Village Household } \\
\text { Dependency Ratio }\end{array}$ & $\begin{array}{l}-3.338 * \\
(0.939)\end{array}$ & $\begin{array}{c}0.119 \\
(0.135)\end{array}$ & $\begin{array}{c}0.147 \\
(0.104)\end{array}$ & $\begin{array}{l}-2.196 * \\
(0.936)\end{array}$ & $\begin{array}{c}0.201 \\
(0.137)\end{array}$ & $\begin{array}{c}0.112 \\
(0.092)\end{array}$ & $\begin{array}{c}-1.994 * \\
(0.912)\end{array}$ & $\begin{array}{c}0.139 \\
(0.130)\end{array}$ & $\begin{array}{c}0.095 \\
(0.114)\end{array}$ \\
\hline $\begin{array}{l}\text { CV of Village Household Dependency } \\
\text { Ratio }\end{array}$ & $\begin{array}{r}-1.257 * \\
(0.545)\end{array}$ & $\begin{array}{l}-0.015 \\
(0.067)\end{array}$ & $\begin{array}{l}0.105 * \\
(0.047)\end{array}$ & $\begin{array}{l}-0.738 \\
(0.412)\end{array}$ & $\begin{array}{c}0.033 \\
(0.078)\end{array}$ & $\begin{array}{c}0.075 \\
(0.046)\end{array}$ & $\begin{array}{l}-0.847 \\
(0.496)\end{array}$ & $\begin{array}{l}-0.030 \\
(0.064)\end{array}$ & $\begin{array}{c}0.094 \\
(0.050)\end{array}$ \\
\hline Log(Productive Assets Per Capita) & - & - & - & $\begin{array}{l}0.169 * \\
(0.057)\end{array}$ & $\begin{array}{c}0.019 * \\
(0.008)\end{array}$ & $\begin{array}{c}-0.010 * \\
(0.005)\end{array}$ & $\begin{array}{l}0.192 * \\
(0.063)\end{array}$ & $\begin{array}{c}0.010 \\
(0.009)\end{array}$ & $\begin{array}{c}-0.009 \\
(0.005)\end{array}$ \\
\hline Share of Assets Managed by Collective & - & - & - & $\begin{array}{c}0.110 \\
(0.185)\end{array}$ & $\begin{array}{c}-0.077 * \\
(0.030)\end{array}$ & $\begin{array}{c}0.016 \\
(0.015)\end{array}$ & $\begin{array}{c}-0.059 \\
(0.194)\end{array}$ & $\begin{array}{c}-0.063 \\
(0.035)\end{array}$ & $\begin{array}{c}0.022 \\
(0.017)\end{array}$ \\
\hline Productive Assets Per Capita Gini & - & - & - & $\begin{array}{c}0.193 \\
(0.281)\end{array}$ & $\begin{array}{c}0.045 \\
(0.045)\end{array}$ & $\begin{array}{c}-0.028 \\
(0.026)\end{array}$ & $\begin{array}{l}-0.230 \\
(0.326)\end{array}$ & $\begin{array}{c}-0.004 \\
(0.049)\end{array}$ & $\begin{array}{c}-0.005 \\
(0.029)\end{array}$ \\
\hline $\begin{array}{l}\mathrm{N} \\
\mathrm{r} 2\end{array}$ & $\begin{array}{c}100 \\
0.669\end{array}$ & $\begin{array}{c}100 \\
0.580\end{array}$ & $\begin{array}{c}100 \\
0.439\end{array}$ & $\begin{array}{c}100 \\
0.689\end{array}$ & $\begin{array}{c}100 \\
0.581\end{array}$ & $\begin{array}{c}100 \\
0.438\end{array}$ & $\begin{array}{c}100 \\
0.741\end{array}$ & $\begin{array}{c}100 \\
0.644\end{array}$ & $\begin{array}{c}100 \\
0.477\end{array}$ \\
\hline
\end{tabular}

Note: All models include province year dummy variables and village location dummies (near city, in hills, and in mountains). Robust standard errors in parentheses. An asterisk $(*)$ indicates a p-value of less than five percent. 
Table 6

The Growth-Inequality Relationship in the Panel

\begin{tabular}{|c|c|c|c|c|c|c|c|c|c|}
\hline \multirow{3}{*}{ Model } & \multicolumn{3}{|c|}{ No Instruments } & \multicolumn{2}{|c|}{$\begin{array}{l}\text { Measurement Error } \\
\text { Instruments }\end{array}$} & \multicolumn{2}{|c|}{$\begin{array}{l}\text { Lean Land } \\
\text { Instruments }\end{array}$} & \multicolumn{2}{|c|}{$\begin{array}{l}\text { Extended Land and } \\
\text { Asset Instruments }\end{array}$} \\
\hline & (1) & (2) & (3) & (4) & $(5)$ & $(6)$ & (7) & $(8)$ & (9) \\
\hline & RE & $\mathrm{FE}$ & FD & RE & $\mathrm{FE}$ & $\mathrm{RE}$ & $\mathrm{FE}$ & $\mathrm{RE}$ & $\mathrm{FE}$ \\
\hline Lagged Gini (Income Per Capita) & $\begin{array}{c}0.051 \\
(0.047)\end{array}$ & $\begin{array}{c}0.115 \\
(0.060)\end{array}$ & $\begin{array}{c}0.069 \\
(0.073)\end{array}$ & $\begin{array}{c}0.048 \\
(0.058)\end{array}$ & $\begin{array}{c}0.138 \\
(0.081)\end{array}$ & $\begin{array}{c}0.042 \\
(0.129)\end{array}$ & $\begin{array}{c}0.041 \\
(0.281)\end{array}$ & $\begin{array}{c}-0.076 \\
(0.092)\end{array}$ & $\begin{array}{c}-0.136 \\
(0.142)\end{array}$ \\
\hline Lagged Log Income Per Capita & $\begin{array}{c}-0.079 * \\
(0.009)\end{array}$ & $\begin{array}{c}-0.187 * \\
(0.012)\end{array}$ & $\begin{array}{c}-0.226^{*} \\
(0.009)\end{array}$ & $\begin{array}{c}-0.048 * \\
(0.018)\end{array}$ & $\begin{array}{c}-0.142 * \\
(0.051)\end{array}$ & $\begin{array}{l}-0.043 \\
(0.023)\end{array}$ & $\begin{array}{l}-0.099 \\
(0.056)\end{array}$ & $\begin{array}{c}-0.022 \\
(0.016)\end{array}$ & $\begin{array}{c}-0.105 * \\
(0.039)\end{array}$ \\
\hline Lagged Log Village Education Per Capita & $\begin{array}{l}0.054 * \\
(0.015)\end{array}$ & $\begin{array}{l}-0.016 \\
(0.038)\end{array}$ & $\begin{array}{c}-0.018 \\
(0.046)\end{array}$ & $\begin{array}{l}0.041 * \\
(0.016)\end{array}$ & $\begin{array}{l}-0.010 \\
(0.041)\end{array}$ & $\begin{array}{l}0.039 * \\
(0.017)\end{array}$ & $\begin{array}{c}-0.003 \\
(0.044)\end{array}$ & $\begin{array}{c}0.030 \\
(0.016)\end{array}$ & $\begin{array}{c}-0.002 \\
(0.045)\end{array}$ \\
\hline Lagged Share of Income from Agriculture & $\begin{array}{c}-0.039 * \\
(0.016)\end{array}$ & $\begin{array}{c}-0.039 \\
(0.029)\end{array}$ & $\begin{array}{c}-0.030 \\
(0.037)\end{array}$ & $\begin{array}{c}-0.027 \\
(0.017)\end{array}$ & $\begin{array}{c}-0.023 \\
(0.033)\end{array}$ & $\begin{array}{c}-0.026 \\
(0.019)\end{array}$ & $\begin{array}{c}-0.018 \\
(0.047)\end{array}$ & $\begin{array}{c}-0.027 \\
(0.018)\end{array}$ & $\begin{array}{c}-0.036 \\
(0.037)\end{array}$ \\
\hline Hausman Test: RE vs FE & \multicolumn{2}{|c|}{$\begin{array}{r}191.56 \\
(0.000)\end{array}$} & & \multicolumn{2}{|c|}{$\begin{array}{c}6.78 \\
(1.270)\end{array}$} & \multicolumn{2}{|c|}{$\begin{array}{c}2.90 \\
(0.821)\end{array}$} & \multicolumn{2}{|c|}{$\begin{array}{c}7.04 \\
(0.317)\end{array}$} \\
\hline Hausman Test: IV vs OLS & & & & $\begin{array}{c}3.92 \\
(0.995)\end{array}$ & $\begin{array}{c}1.27 \\
(0.973)\end{array}$ & $\begin{array}{c}2.79 \\
(1.000)\end{array}$ & $\begin{array}{c}4.48 \\
(0.612)\end{array}$ & $\begin{array}{c}18.74 \\
(0.344)\end{array}$ & $\begin{array}{c}7.69 \\
(0.262)\end{array}$ \\
\hline F-Test for Excluded Instruments $\left(\mathrm{y}_{\mathrm{t}-1}\right)$ & & & & $\begin{array}{l}152.44 \\
(0.000)\end{array}$ & $\begin{array}{c}14.20 \\
(0.000)\end{array}$ & $\begin{array}{c}51.27 \\
(0.000)\end{array}$ & $\begin{array}{c}9.79 \\
(0.000)\end{array}$ & $\begin{array}{l}102.37 \\
(0.000)\end{array}$ & $\begin{array}{c}2.63 \\
(0.004)\end{array}$ \\
\hline F-Test for Excluded Instruments $\left(\mathrm{G}_{\mathrm{t}-1}\right)$ & & & & $\begin{array}{c}97.79 \\
(0.000)\end{array}$ & $\begin{array}{c}40.93 \\
(0.000)\end{array}$ & $\begin{array}{c}53.78 \\
(0.000)\end{array}$ & $\begin{array}{c}9.88 \\
(0.000)\end{array}$ & $\begin{array}{c}93.30 \\
(0.000)\end{array}$ & $\begin{array}{c}5.26 \\
(0.000)\end{array}$ \\
\hline $\begin{array}{l}\text { Over-ID Test } \\
\text { Chi-Probability }\end{array}$ & & & & $\begin{array}{c}0.16 \\
(0.690)\end{array}$ & $\begin{array}{c}0.27 \\
(0.605)\end{array}$ & $\begin{array}{c}0.76 \\
(0.675)\end{array}$ & $\begin{array}{c}1.16 \\
(0.561)\end{array}$ & $\begin{array}{c}8.48 \\
(0.487)\end{array}$ & $\begin{array}{c}6.76 \\
(0.663)\end{array}$ \\
\hline $\mathrm{N}$ & 299 & 299 & 199 & 299 & 299 & 299 & 299 & 298 & 298 \\
\hline $\mathrm{r} 2$ & 0.362 & 0.640 & 0.744 & - & - & - & - & - & - \\
\hline
\end{tabular}

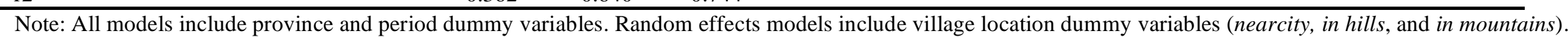

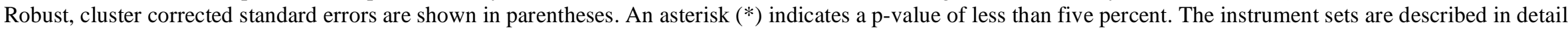
in the notes to Table 4 . 
Table 7

Initial Inequality and the Growth of Income from Different Activities

\begin{tabular}{|c|c|c|c|c|c|c|c|c|c|c|c|c|}
\hline \multirow{3}{*}{$\begin{array}{l}\text { Model } \\
\text { Variable }\end{array}$} & \multicolumn{4}{|c|}{ OLS } & \multicolumn{4}{|c|}{ IV: Lean Cultivable Land Instruments } & \multicolumn{4}{|c|}{ IV: Extended Instrument Set } \\
\hline & (1) & (2) & (3) & (4) & (5) & (6) & (7) & (8) & (9) & (10) & (11) & (12) \\
\hline & $\Delta \ln ($ Crop) & $\Delta \ln ($ Non $\mathrm{Ag})$ & $\Delta \ln ($ Wage $)$ & $\Delta \ln ($ Bus $)$ & $\Delta \ln ($ Crop $)$ & $\Delta \ln (\mathrm{NonAg})$ & $\Delta \ln ($ Wage $)$ & $\Delta \ln ($ Bus $)$ & $\Delta \ln ($ Crop $)$ & $\Delta \ln (\operatorname{NonAg})$ & $\Delta \ln ($ Wage $)$ & $\Delta \ln (\mathrm{Bus})$ \\
\hline $\begin{array}{l}\text { Gini (Income Per } \\
\text { Capita) }\end{array}$ & $\begin{array}{c}0.154 \\
(0.092)\end{array}$ & $\begin{array}{l}-0.264^{*} \\
(0.080)\end{array}$ & $\begin{array}{l}-0.309^{*} \\
(0.093)\end{array}$ & $\begin{array}{c}0.067 \\
(0.177)\end{array}$ & $\begin{array}{c}0.263 \\
(0.256)\end{array}$ & $\begin{array}{l}-0.653^{*} \\
(0.187)\end{array}$ & $\begin{array}{l}-0.364 \\
(0.219)\end{array}$ & $\begin{array}{l}-0.654 \\
(0.484)\end{array}$ & $\begin{array}{c}0.105 \\
(0.196)\end{array}$ & $\begin{array}{l}-0.622 * \\
(0.152)\end{array}$ & $\begin{array}{l}-0.465^{*} \\
(0.156)\end{array}$ & $\begin{array}{l}-0.606 \\
(0.322)\end{array}$ \\
\hline $\ln ($ Crop Inc PC) & $\begin{array}{l}-0.060^{*} \\
(0.014)\end{array}$ & $\begin{array}{l}- \\
-\end{array}$ & $\begin{array}{l}- \\
-\end{array}$ & $\begin{array}{l}- \\
-\end{array}$ & $\begin{array}{l}-0.010 \\
(0.030)\end{array}$ & $\begin{array}{l}- \\
-\end{array}$ & $\begin{array}{l}- \\
-\end{array}$ & $\begin{array}{l}- \\
-\end{array}$ & $\begin{array}{l}-0.026 \\
(0.027)\end{array}$ & $\begin{array}{l}- \\
-\end{array}$ & $\begin{array}{l}- \\
-\end{array}$ & $\begin{array}{l}- \\
-\end{array}$ \\
\hline $\begin{array}{l}\ln (\text { Non Ag Income } \\
\text { PC) }\end{array}$ & $\begin{array}{l}- \\
-\end{array}$ & $\begin{array}{l}-0.030^{*} \\
(0.009)\end{array}$ & $\begin{array}{l}- \\
-\end{array}$ & $\begin{array}{l}- \\
-\end{array}$ & $\begin{array}{l}- \\
-\end{array}$ & $\begin{array}{l}-0.034 * \\
(0.013)\end{array}$ & $\begin{array}{l}- \\
-\end{array}$ & $\begin{array}{l}- \\
-\end{array}$ & $\begin{array}{l}- \\
-\end{array}$ & $\begin{array}{l}-0.037 * \\
(0.012)\end{array}$ & $\begin{array}{l}- \\
-\end{array}$ & $\begin{array}{l}- \\
-\end{array}$ \\
\hline $\ln$ (Wage Income PC) & $\begin{array}{l}- \\
-\end{array}$ & - & $\begin{array}{l}-0.042 * \\
(0.007)\end{array}$ & $\begin{array}{l}- \\
-\end{array}$ & $\begin{array}{l}- \\
-\end{array}$ & $\begin{array}{l}- \\
-\end{array}$ & $\begin{array}{l}-0.045^{*} \\
(0.010)\end{array}$ & $\begin{array}{l}- \\
-\end{array}$ & $\begin{array}{l}- \\
-\end{array}$ & $\begin{array}{l}- \\
-\end{array}$ & $\begin{array}{l}-0.050^{*} \\
(0.009)\end{array}$ & $\begin{array}{l}- \\
-\end{array}$ \\
\hline $\begin{array}{l}\ln (\mathrm{HH} \text { Business Inc } \\
\mathrm{PC})\end{array}$ & $\begin{array}{l}- \\
-\end{array}$ & - & - & $\begin{array}{l}-0.053^{*} \\
(0.009)\end{array}$ & $\begin{array}{l}- \\
-\end{array}$ & $\begin{array}{l}- \\
-\end{array}$ & $\begin{array}{l}- \\
-\end{array}$ & $\begin{array}{l}-0.042 * \\
(0.021)\end{array}$ & $\begin{array}{l}- \\
-\end{array}$ & - & - & $\begin{array}{l}-0.043^{*} \\
(0.015)\end{array}$ \\
\hline $\begin{array}{l}\ln (\text { Village Education } \\
\text { PC) }\end{array}$ & $\begin{array}{c}0.048 \\
(0.025)\end{array}$ & $\begin{array}{l}0.064 * \\
(0.025)\end{array}$ & $\begin{array}{l}0.096^{*} \\
(0.029)\end{array}$ & $\begin{array}{l}-0.004 \\
(0.047)\end{array}$ & $\begin{array}{c}0.022 \\
(0.033)\end{array}$ & $\begin{array}{l}0.052^{*} \\
(0.027)\end{array}$ & $\begin{array}{l}0.096^{*} \\
(0.032)\end{array}$ & $\begin{array}{l}-0.031 \\
(0.047)\end{array}$ & $\begin{array}{c}0.026 \\
(0.030)\end{array}$ & $\begin{array}{l}0.055^{*} \\
(0.027)\end{array}$ & $\begin{array}{l}0.096^{*} \\
(0.030)\end{array}$ & $\begin{array}{l}-0.029 \\
(0.045)\end{array}$ \\
\hline $\begin{array}{l}\text { Share of Income } \\
\text { from Agriculture }\end{array}$ & $\begin{array}{l}0.175^{*} \\
(0.044)\end{array}$ & $\begin{array}{l}-0.020 \\
(0.042)\end{array}$ & $\begin{array}{l}-0.053 \\
(0.046)\end{array}$ & $\begin{array}{l}-0.049 \\
(0.058)\end{array}$ & $\begin{array}{l}0.073 \\
(0.092)\end{array}$ & $\begin{array}{l}-0.093 \\
(0.070)\end{array}$ & $\begin{array}{l}-0.073 \\
(0.068)\end{array}$ & $\begin{array}{l}-0.126 \\
(0.093)\end{array}$ & $\begin{array}{c}0.086 \\
(0.075)\end{array}$ & $\begin{array}{l}-0.098 \\
(0.057)\end{array}$ & $\begin{array}{l}-0.103 \\
(0.055)\end{array}$ & $\begin{array}{l}-0.121 \\
(0.065)\end{array}$ \\
\hline $\begin{array}{l}\text { F-Stat Initial Income } \\
\text { Component: }\end{array}$ & & & & & $\begin{array}{c}3.19 \\
(0.011)\end{array}$ & $\begin{array}{c}9.99 \\
(0.000)\end{array}$ & $\begin{array}{c}6.38 \\
(0.000)\end{array}$ & $\begin{array}{c}4.09 \\
(0.000)\end{array}$ & $\begin{array}{c}2.32 \\
(0.016)\end{array}$ & $\begin{array}{c}8.12 \\
(0.000)\end{array}$ & $\begin{array}{c}6.65 \\
(0.000)\end{array}$ & $\begin{array}{c}5.30 \\
(0.000)\end{array}$ \\
\hline F-Stat Gini & & & & & $\begin{array}{c}3.07 \\
(0.014)\end{array}$ & $\begin{array}{c}3.07 \\
(0.014)\end{array}$ & $\begin{array}{c}3.07 \\
(0.014)\end{array}$ & $\begin{array}{c}3.07 \\
(0.014)\end{array}$ & $\begin{array}{c}2.65 \\
(0.006)\end{array}$ & $\begin{array}{c}2.65 \\
(0.006)\end{array}$ & $\begin{array}{c}2.65 \\
(0.006)\end{array}$ & $\begin{array}{c}2.65 \\
(0.006)\end{array}$ \\
\hline $\begin{array}{l}\text { Over-ID } \\
\quad \text { Chi-Probability }\end{array}$ & & & & & $\begin{array}{c}1.07 \\
(0.783)\end{array}$ & $\begin{array}{c}1.08 \\
(0.781)\end{array}$ & $\begin{array}{c}0.84 \\
(0.841)\end{array}$ & $\begin{array}{c}2.58 \\
(4.590)\end{array}$ & $\begin{array}{c}8.83 \\
(0.453)\end{array}$ & $\begin{array}{c}3.46 \\
(0.943)\end{array}$ & $\begin{array}{c}4.50 \\
(0.876)\end{array}$ & $\begin{array}{c}3.89 \\
(0.919)\end{array}$ \\
\hline $\mathrm{N}$ & 100 & 100 & 100 & 100 & 100 & 100 & 100 & 100 & 100 & 100 & 100 & 100 \\
\hline $\mathrm{r} 2$ & 0.334 & 0.492 & 0.513 & 0.418 & - & - & - & - & - & - & - & - \\
\hline
\end{tabular}


Table 8

Is the Growth-Inequality Relationship Driven by Presence of TVEs?

\begin{tabular}{|c|c|c|c|c|c|c|c|c|c|}
\hline \multirow[b]{2}{*}{ Variable } & \multicolumn{3}{|c|}{ OLS } & \multicolumn{3}{|c|}{ IV: Lean Land Instruments } & \multicolumn{3}{|c|}{ IV: Extended Instrument Set } \\
\hline & $\Delta \ln (\mathrm{Inc})$ & $\Delta \ln ($ Crop $)$ & $\Delta \ln ($ Non $\mathrm{Ag})$ & $\Delta \ln (\operatorname{Inc})$ & $\Delta \ln ($ Crop) & $\Delta \ln ($ NonAg) & $\Delta \ln (\operatorname{Inc})$ & $\Delta \ln ($ Crop) & $\Delta \ln ($ Non $\mathrm{Ag})$ \\
\hline Gini (Income Per Capita) & $\begin{array}{l}-0.072 \\
(0.048)\end{array}$ & $\begin{array}{c}0.162 \\
(0.091)\end{array}$ & $\begin{array}{r}-0.266^{*} \\
(0.080)\end{array}$ & $\begin{array}{r}-0.261^{*} \\
(0.124)\end{array}$ & $\begin{array}{c}0.197 \\
(0.297)\end{array}$ & $\begin{array}{l}-0.729 * \\
(0.260)\end{array}$ & $\begin{array}{l}-0.208 * \\
(0.074)\end{array}$ & $\begin{array}{c}0.019 \\
(0.214)\end{array}$ & $\begin{array}{r}-0.494 * \\
(0.156)\end{array}$ \\
\hline $\ln ($ Vill Mean Inc Pc) & $\begin{array}{c}-0.054 * \\
0.008\end{array}$ & $\begin{array}{l}- \\
-\end{array}$ & $\begin{array}{l}- \\
-\end{array}$ & $\begin{array}{l}-0.057^{*} \\
(0.020)\end{array}$ & $\begin{array}{l}- \\
-\end{array}$ & $\begin{array}{l}- \\
-\end{array}$ & $\begin{array}{l}-0.054 * \\
(0.014)\end{array}$ & $\begin{array}{l}- \\
-\end{array}$ & $\begin{array}{l}- \\
-\end{array}$ \\
\hline $\ln ($ Crop Inc PC) & $\begin{array}{l}- \\
-\end{array}$ & $\begin{array}{r}-0.054 * \\
(0.014)\end{array}$ & $\begin{array}{l}- \\
-\end{array}$ & $\begin{array}{l}- \\
-\end{array}$ & $\begin{array}{c}0.007 \\
(0.043)\end{array}$ & $\begin{array}{l}- \\
-\end{array}$ & $\begin{array}{l}- \\
-\end{array}$ & $\begin{array}{l}0.000 \\
(0.039)\end{array}$ & $\begin{array}{l}- \\
-\end{array}$ \\
\hline $\ln ($ Non Ag Income PC) & $\begin{array}{l}- \\
-\end{array}$ & $\begin{array}{l}- \\
-\end{array}$ & $\begin{array}{r}-0.033 * \\
(0.009)\end{array}$ & $\begin{array}{l}- \\
-\end{array}$ & $\begin{array}{l}- \\
-\end{array}$ & $\begin{array}{l}-0.042^{*} \\
(0.015)\end{array}$ & $\begin{array}{l}- \\
-\end{array}$ & $\begin{array}{l}- \\
-\end{array}$ & $\begin{array}{r}-0.044 * \\
(0.012)\end{array}$ \\
\hline Number of TVEs in 1993 & $\begin{array}{c}0.002 \\
(0.001)\end{array}$ & $\begin{array}{l}-0.002 \\
(0.002)\end{array}$ & $\begin{array}{l}0.003 \\
(0.002)\end{array}$ & $\begin{array}{c}0.002 \\
(0.001)\end{array}$ & $\begin{array}{l}-0.005 \\
(0.003)\end{array}$ & $\begin{array}{c}0.003 \\
(0.002)\end{array}$ & $\begin{array}{c}0.002 \\
(0.001)\end{array}$ & $\begin{array}{l}-0.004 \\
(0.003)\end{array}$ & $\begin{array}{c}0.003 \\
(0.002)\end{array}$ \\
\hline $\ln ($ Village Education PC) & $\begin{array}{l}0.047 * \\
(0.013)\end{array}$ & $\begin{array}{l}0.052^{*} \\
(0.025)\end{array}$ & $\begin{array}{l}0.056^{*} \\
(0.027)\end{array}$ & $\begin{array}{l}0.040^{*} \\
(0.015)\end{array}$ & $\begin{array}{l}0.026 \\
(0.034)\end{array}$ & $\begin{array}{c}0.042 \\
(0.029)\end{array}$ & $\begin{array}{l}0.041 * \\
(0.014)\end{array}$ & $\begin{array}{c}0.022 \\
(0.031)\end{array}$ & $\begin{array}{l}0.051 * \\
(0.027)\end{array}$ \\
\hline $\begin{array}{l}\text { Share of Income from } \\
\text { Agriculture }\end{array}$ & $\begin{array}{l}-0.026 \\
(0.018)\end{array}$ & $\begin{array}{l}0.148^{*} \\
(0.049)\end{array}$ & $\begin{array}{l}-0.018 \\
(0.042)\end{array}$ & $\begin{array}{l}-0.055 \\
(0.031)\end{array}$ & $\begin{array}{c}0.000 \\
(0.123)\end{array}$ & $\begin{array}{l}-0.116 \\
(0.085)\end{array}$ & $\begin{array}{l}-0.046 \\
(0.024)\end{array}$ & $\begin{array}{l}-0.010 \\
(0.111)\end{array}$ & $\begin{array}{l}-0.085 \\
(0.060)\end{array}$ \\
\hline $\begin{array}{l}\text { F-Stat Initial Income } \\
\text { Component: }\end{array}$ & $\begin{array}{l}- \\
-\end{array}$ & $\begin{array}{l}- \\
-\end{array}$ & $\begin{array}{l}- \\
-\end{array}$ & $\begin{array}{c}3.70 \\
(0.005)\end{array}$ & $\begin{array}{c}2.13 \\
(0.070)\end{array}$ & $\begin{array}{c}2.29 \\
(0.053)\end{array}$ & $\begin{array}{c}2.93 \\
(0.003)\end{array}$ & $\begin{array}{c}1.33 \\
(0.223)\end{array}$ & $\begin{array}{c}6.98 \\
(0.000)\end{array}$ \\
\hline F-Stat Gini & $\begin{array}{l}- \\
-\end{array}$ & $\begin{array}{l}- \\
-\end{array}$ & $\begin{array}{l}- \\
-\end{array}$ & $\begin{array}{c}2.35 \\
(0.048)\end{array}$ & $\begin{array}{c}2.35 \\
(0.048)\end{array}$ & $\begin{array}{c}2.35 \\
(0.048)\end{array}$ & $\begin{array}{c}3.04 \\
(0.021)\end{array}$ & $\begin{array}{c}3.04 \\
(0.021)\end{array}$ & $\begin{array}{c}3.04 \\
(0.021)\end{array}$ \\
\hline $\begin{array}{l}\text { Over-ID } \\
\quad \text { (Chi-Probability) }\end{array}$ & $\begin{array}{l}- \\
-\end{array}$ & $\begin{array}{l}- \\
-\end{array}$ & $\begin{array}{l}- \\
-\end{array}$ & $\begin{array}{c}1.98 \\
(0.576)\end{array}$ & $\begin{array}{c}0.35 \\
(0.950)\end{array}$ & $\begin{array}{c}1.86 \\
(0.602)\end{array}$ & $\begin{array}{c}3.48 \\
(0.942)\end{array}$ & $\begin{array}{l}10.24 \\
(0.331)\end{array}$ & $\begin{array}{c}7.89 \\
(0.545)\end{array}$ \\
\hline $\begin{array}{l}\text { T-Statistics on Share of As } \\
\text { Reduced Form Growth } \\
\text { First Stage for Gini } \\
\text { First Stage for } \ln \text { (income) }\end{array}$ & $\begin{array}{c}\text { Collectiv } \\
- \\
- \\
-\end{array}$ & $\begin{array}{l}- \\
-\end{array}$ & $\begin{array}{l}- \\
- \\
-\end{array}$ & $\begin{array}{l}- \\
- \\
-\end{array}$ & $\begin{array}{l}- \\
- \\
-\end{array}$ & $\begin{array}{l}- \\
-\end{array}$ & $\begin{array}{r}1.26 \\
-3.01 \\
-0.72\end{array}$ & $\begin{array}{c}0.67 \\
-3.01 \\
0.99\end{array}$ & $\begin{array}{c}0.24 \\
-3.01 \\
0.07\end{array}$ \\
\hline $\begin{array}{l}\mathrm{N} \\
\mathrm{r} 2\end{array}$ & $\begin{array}{c}100 \\
0.334\end{array}$ & $\begin{array}{c}100 \\
0.492\end{array}$ & $\begin{array}{c}100 \\
0.513\end{array}$ & $\begin{array}{c}100 \\
-\end{array}$ & $\begin{array}{c}100 \\
-\end{array}$ & $\begin{array}{c}100 \\
-\end{array}$ & $\begin{array}{c}100 \\
-\end{array}$ & $\begin{array}{c}100 \\
-\end{array}$ & $\begin{array}{c}100 \\
-\end{array}$ \\
\hline
\end{tabular}

Instruments:
Lean Land Instruments (The Lean Set): Cultivated land gini, cultivated land per capita, other land per capita, village average dependency ratio, coefficient of variation of household dependency ratios.

Extended Land Instruments and Asset Instruments (The Fat Set): Lean land instruments, plus $\ln$ (productive assets per capita), gini (productive assets per capita), share of village assets controlled by collective, percent of hh other land (forest or fishpond land), percent with other land interacted with other land per capita, share of cultivated land managed by collective, and share of other land managed by the collective.

Notes: All models include jointly significant province dummy variables and village location dummy variables. Robust standard errors shown in parentheses. An asterisk (*) indicates a p-value of less than five percent. 
Table 9

Household Income Growth and Interactions Between Initial Income and Inequality

\begin{tabular}{|c|c|c|c|c|c|c|}
\hline \multirow[b]{2}{*}{ Model } & \multicolumn{2}{|c|}{ OLS } & \multicolumn{2}{|c|}{$\begin{array}{l}\text { HH ME \& Lean } \\
\text { Land Instruments } \\
\text { \& Interactions }\end{array}$} & \multicolumn{2}{|c|}{$\begin{array}{c}\text { HH ME \& Extended } \\
\text { Farm and Asset } \\
\text { Instruments \& } \\
\text { Interactions }\end{array}$} \\
\hline & 1 & 2 & 3 & 4 & 5 & 6 \\
\hline Gini (Income Per Capita) & $\begin{array}{r}-0.102^{*} \\
(0.045)\end{array}$ & $\begin{array}{c}0.160 \\
(0.294)\end{array}$ & $\begin{array}{l}-0.241 \\
(0.151)\end{array}$ & $\begin{array}{l}-0.494 \\
(1.225)\end{array}$ & $\begin{array}{r}-0.257 * \\
(0.106)\end{array}$ & $\begin{array}{l}-0.651 \\
(0.773)\end{array}$ \\
\hline $\begin{array}{l}\text { (Income Gini)* } \ln (\text { Household Income } \\
\text { Per Capita) }\end{array}$ & - & $\begin{array}{l}-0.042 \\
(0.048)\end{array}$ & - & $\begin{array}{c}0.040 \\
(0.200)\end{array}$ & $\begin{array}{l}- \\
-\end{array}$ & $\begin{array}{l}0.066 \\
(0.125)\end{array}$ \\
\hline $\ln$ (Village Average Income Per Capita) & $\begin{array}{l}0.021 * \\
(0.007)\end{array}$ & $\begin{array}{l}0.019^{*} \\
(0.007)\end{array}$ & $\begin{array}{c}0.047 \\
(0.030)\end{array}$ & $\begin{array}{l}0.054^{*} \\
(0.027)\end{array}$ & $\begin{array}{c}0.033 \\
(0.022)\end{array}$ & $\begin{array}{l}0.049^{*} \\
(0.018)\end{array}$ \\
\hline ln(Household Income Per Capita) & $\begin{array}{r}-0.075^{*} \\
(0.003)\end{array}$ & $\begin{array}{l}-0.063^{*} \\
(0.013)\end{array}$ & $\begin{array}{l}-0.066^{*} \\
(0.019)\end{array}$ & $\begin{array}{l}-0.085 \\
(0.052)\end{array}$ & $\begin{array}{l}-0.060 * \\
(0.018)\end{array}$ & $\begin{array}{l}-0.096^{*} \\
(0.036)\end{array}$ \\
\hline $\begin{array}{l}\text { Share of Village Income From } \\
\text { Agriculture }\end{array}$ & $\begin{array}{l}-0.024 \\
(0.015)\end{array}$ & $\begin{array}{l}-0.023 \\
(0.015)\end{array}$ & $\begin{array}{l}-0.037 \\
(0.032)\end{array}$ & $\begin{array}{l}-0.040 \\
(0.029)\end{array}$ & $\begin{array}{l}-0.040 \\
(0.025)\end{array}$ & $\begin{array}{l}-0.041 \\
(0.021)\end{array}$ \\
\hline $\begin{array}{l}\ln \text { (Village Average Education Per } \\
\text { Capita) }\end{array}$ & $\begin{array}{l}0.044^{*} \\
(0.014)\end{array}$ & $\begin{array}{l}0.045^{*} \\
(0.014)\end{array}$ & $\begin{array}{l}0.039 * \\
(0.017)\end{array}$ & $\begin{array}{l}0.038^{*} \\
(0.016)\end{array}$ & $\begin{array}{l}0.041^{*} \\
(0.017)\end{array}$ & $\begin{array}{l}0.039^{*} \\
(0.016)\end{array}$ \\
\hline F-Stat Income Gini & $\begin{array}{l}- \\
-\end{array}$ & - & $\begin{array}{c}4.26 \\
(0.000)\end{array}$ & $\begin{array}{c}3.42 \\
(0.000)\end{array}$ & $\begin{array}{c}4.71 \\
(0.000)\end{array}$ & $\begin{array}{c}11.62 \\
(0.000)\end{array}$ \\
\hline F-Stat Gini-ln(HH IPC) Interaction & - & - & - & $\begin{array}{c}4.62 \\
(0.000)\end{array}$ & - & $\begin{array}{c}13.45 \\
(0.000)\end{array}$ \\
\hline F-Stat ln (HH IPC) & - & - & $\begin{array}{c}11.29 \\
(0.000)\end{array}$ & $\begin{array}{c}7.17 \\
(0.000)\end{array}$ & $\begin{array}{c}18.30 \\
(0.000)\end{array}$ & $\begin{array}{c}12.83 \\
(0.000)\end{array}$ \\
\hline F-Stat $\ln ($ Village IPC) & - & - & $\begin{array}{c}5.20 \\
(0.000)\end{array}$ & $\begin{array}{c}3.44 \\
(0.000)\end{array}$ & $\begin{array}{c}11.45 \\
(0.000)\end{array}$ & $\begin{array}{c}9.98 \\
(0.000)\end{array}$ \\
\hline $\begin{array}{l}\text { Over-ID } \\
\quad \text { (Chi-Probability) } \\
\text { Degrees of Freedom }\end{array}$ & - & - & $\begin{array}{c}1.60 \\
(0.659) \\
3\end{array}$ & $\begin{array}{c}113.50 \\
(0.000) \\
8\end{array}$ & $\begin{array}{c}11.45 \\
(0.000) \\
9\end{array}$ & $\begin{array}{c}91.40 \\
(0.000) \\
28\end{array}$ \\
\hline $\begin{array}{l}\mathrm{N} \\
\mathrm{r} 2\end{array}$ & $\begin{array}{c}4434 \\
0.4432\end{array}$ & $\begin{array}{c}4434 \\
0.4439\end{array}$ & $\begin{array}{c}4434 \\
-\end{array}$ & $\begin{array}{c}4434 \\
-\end{array}$ & $\begin{array}{c}4434 \\
-\end{array}$ & $\begin{array}{c}4434 \\
-\end{array}$ \\
\hline
\end{tabular}

Instruments:

Model 3: Household measurement error instruments (HH ME) include $\ln (1+$ wage income per capita) and $\ln (1+$ household non-agricultural income per capita), plus lean land instruments for the gini (income) and income: Cultivated land gini, cultivated land per capita, other land per capita, village average dependency ratio, coefficient of variation of household dependency ratios.

Model 4: Model 3 instruments and interactions between household and village level instruments.

Model 5: Model 3 instruments plus the following village level instruments: ln(productive assets per capita), gini (productive assets per capita), share of village assets controlled by collective, percent of hh other land (forest or fishpond land), percent with other land interacted with other land per capita, share of cultivated land managed by collective, and share of other land managed by the collective

Model 6: Model 5 instruments and interactions between household and village level instruments.

Notes: Household controls (not shown) in Models 1 and 2 include $\ln (\mathrm{HH}$ average education per capita), household size, household dependency ratio, male share of working age adults, household cultivated land per capita, $\ln$ (value of household assets per capita. All models include province dummy variables and three location dummy variables: for whether the village is near a city, in the mountains, or in the hills. Robust, cluster corrected standard errors in parentheses. An asterisk (*) indicates a p-value of less than five percent. 
Table 10

Is Their a Relationship Between Village Revenues or Expenditures and Inequality?

\begin{tabular}{|c|c|c|c|c|c|c|}
\hline \multirow[b]{2}{*}{ Model } & \multicolumn{3}{|c|}{ Dep Var: $\ln ($ village revenue per capita) } & \multicolumn{3}{|c|}{ Dep Var: $\ln$ (village expenditures per capita) } \\
\hline & 1 & $\begin{array}{c}2 \\
\text { Measurement } \\
\text { Error } \\
\text { Instruments }\end{array}$ & $\begin{array}{c}3 \\
\text { Extended } \\
\text { Land and } \\
\text { Asset } \\
\text { Instruments }\end{array}$ & 4 & $\begin{array}{c}5 \\
\text { Measurement } \\
\text { Error } \\
\text { Instruments }\end{array}$ & $\begin{array}{c}6 \\
\text { Extended } \\
\text { Land and } \\
\text { Asset } \\
\text { Instruments }\end{array}$ \\
\hline Gini (Income Per Capita) & $\begin{array}{l}-0.76 \\
(1.82)\end{array}$ & $\begin{array}{l}-1.89 \\
(2.13)\end{array}$ & $\begin{array}{l}-4.80 \\
(4.23)\end{array}$ & $\begin{array}{l}-0.86 \\
(1.78)\end{array}$ & $\begin{array}{l}-1.75 \\
(2.07)\end{array}$ & $\begin{array}{l}-4.91 \\
(4.16)\end{array}$ \\
\hline Ln(Village Income Per Capita) & $\begin{array}{l}1.17 * \\
(0.26)\end{array}$ & $\begin{array}{l}1.38^{*} \\
(0.34)\end{array}$ & $\begin{array}{l}1.96^{*} \\
(0.30)\end{array}$ & $\begin{array}{l}1.18 * \\
(0.25)\end{array}$ & $\begin{array}{l}1.37 * \\
(0.32)\end{array}$ & $\begin{array}{l}2.02 * \\
(0.30)\end{array}$ \\
\hline $\begin{array}{l}\text { Ln(Village Average Ed Per } \\
\text { Capita) }\end{array}$ & $\begin{array}{c}0.88 \\
(0.71)\end{array}$ & $\begin{array}{c}0.73 \\
(0.75)\end{array}$ & $\begin{array}{c}0.33 \\
(0.81)\end{array}$ & $\begin{array}{c}0.83 \\
(0.66)\end{array}$ & $\begin{array}{c}0.70 \\
(0.70)\end{array}$ & $\begin{array}{c}0.26 \\
(0.77)\end{array}$ \\
\hline $\begin{array}{l}\text { Agricultural Income as a Share } \\
\text { of Total Income }\end{array}$ & $\begin{array}{l}-1.69 * \\
(0.52)\end{array}$ & $\begin{array}{l}-1.82 * \\
(0.52)\end{array}$ & $\begin{array}{l}-2.14^{*} \\
(0.83)\end{array}$ & $\begin{array}{l}-1.60 * \\
(0.50)\end{array}$ & $\begin{array}{l}-1.70^{*} \\
(0.50)\end{array}$ & $\begin{array}{l}-2.05^{*} \\
(0.82)\end{array}$ \\
\hline $\begin{array}{l}\text { Over-Identification } \\
\text { Chi-Square Statistic } \\
\text { (Chi-Probability) }\end{array}$ & & $\begin{array}{c}3.53 \\
(0.062)\end{array}$ & $\begin{array}{c}23.20 \\
(0.012)\end{array}$ & & $\begin{array}{c}3.43 \\
(0.064)\end{array}$ & $\begin{array}{c}21.86 \\
(0.020)\end{array}$ \\
\hline $\begin{array}{l}\text { The First Stage } \\
\text { Ln(Vill IPC) } \\
\end{array}$ & & 17.21 & 11.01 & & 17.21 & 11.01 \\
\hline Probability) & & $(0.000)$ & $(0.000)$ & & $(0.000)$ & $(0.000)$ \\
\hline $\begin{array}{ll}\text { IPC Gini } & \text { F-Test } \\
& (\mathrm{F}-\end{array}$ & & 31.66 & 6.41 & & 31.66 & 6.41 \\
\hline Probability) & & $(0.000)$ & $(0.000)$ & & $(0.000)$ & $(0.000)$ \\
\hline $\begin{array}{l}\mathrm{N} \\
\mathrm{R} 2\end{array}$ & $\begin{array}{r}100 \\
0.57\end{array}$ & $\begin{array}{c}100 \\
--\end{array}$ & $\begin{array}{c}100 \\
--\end{array}$ & $\begin{array}{c}100 \\
0.58\end{array}$ & $\begin{array}{c}100 \\
--\end{array}$ & $\begin{array}{c}100 \\
--\end{array}$ \\
\hline $\begin{array}{l}\text { Instruments: } \\
\text { Measurement Error Instruments } \\
\text { income per capita). } \\
\text { Extended Land Instruments and } \\
\text { assets controlled by collective, c } \\
\text { coefficient of variation of house } \\
\text { interacted with other land per ca } \\
\text { collective. } \\
\text { Notes: All models include joint } \\
\text { errors shown in parentheses. An }\end{array}$ & $\begin{array}{l}\text { y/ten in } \\
\text { Instrume } \\
\text { ed land } \\
\text { ependen } \\
\text { lare of } \mathrm{c} \\
\text { ificant } \mathrm{p} \\
\text { (*) in }\end{array}$ & $\begin{array}{l}\text { e per capita rati } \\
\ln \text { (productive a } \\
\text { cultivated land } \\
\text { tios, percent of } \\
\text { ated land mana } \\
\text { nce dummy var } \\
\text { es a p-value of }\end{array}$ & $\begin{array}{l}\text { seventy-five/ } \\
\text { ets per capita) } \\
\text { er capita, othe } \\
\text { h other land ( } \\
\text { d by collectiv } \\
\text { bles and villas } \\
\text { ss than five pe }\end{array}$ & $\begin{array}{l}\text {-five incor } \\
\text { productiv } \\
\text { per capita, } \\
\text { r fishpond } \\
\text { share of o } \\
\text { tion dumn }\end{array}$ & $\begin{array}{l}\text { er capita ratio, } 1 \\
\text { ets per capita), } \\
\text { age average dep } \\
\text { l), percent with } \\
\text { and managed b } \\
\text { riables. Robus }\end{array}$ & $\begin{array}{l}\text { average wage } \\
\text { are of village } \\
\text { hdency ratio, } \\
\text { ther land } \\
\text { the } \\
\text { tandard }\end{array}$ \\
\hline
\end{tabular}


Table 11

Is Their a Relationship the Structure of Village Public Finances and Inequality?

\begin{tabular}{|c|c|c|c|c|c|c|c|c|c|}
\hline \multirow{2}{*}{$\begin{array}{l}\text { Dependent Variable } \\
\text { Model }\end{array}$} & \multicolumn{3}{|c|}{$\ln ($ Village Tax \& Fees Per Capita) } & \multicolumn{3}{|c|}{ Weighted Average Village Tax Rate } & \multicolumn{3}{|c|}{$\begin{array}{c}\text { (Tax Rate of Upper } 25 \%) /(\text { Tax Rate of } \\
\text { Lower } 25 \% \text { ) }\end{array}$} \\
\hline & $\begin{array}{c}1 \\
\text { OLS }\end{array}$ & $\begin{array}{c}2 \\
\text { Meas. } \\
\text { Error } \\
\text { Instruments }\end{array}$ & $\begin{array}{c}3 \\
\text { Fat Land } \\
\text { and Asset } \\
\text { Instruments }\end{array}$ & $\begin{array}{c}4 \\
\text { OLS }\end{array}$ & $\begin{array}{c}5 \\
\text { Meas. } \\
\text { Error } \\
\text { Instruments }\end{array}$ & $\begin{array}{c}6 \\
\text { Fat Land } \\
\text { and Asset } \\
\text { Instruments }\end{array}$ & $\begin{array}{c}7 \\
\text { OLS }\end{array}$ & $\begin{array}{c}8 \\
\text { Meas. Error } \\
\text { Instruments }\end{array}$ & $\begin{array}{c}9 \\
\text { Fat Land } \\
\text { and Asset } \\
\text { Instruments }\end{array}$ \\
\hline Gini (Income Per Capita) & $\begin{array}{c}2.291 \\
(1.912)\end{array}$ & $\begin{array}{c}2.732 \\
(1.626)\end{array}$ & $\begin{array}{c}2.329 \\
(2.648)\end{array}$ & $\begin{array}{c}0.078 \\
(0.055)\end{array}$ & $\begin{array}{c}0.092 \\
(0.050)\end{array}$ & $\begin{array}{c}0.169 \\
(0.087)\end{array}$ & $\begin{array}{l}-1.287 \\
(0.652)\end{array}$ & $\begin{array}{l}-1.567 * \\
(0.515)\end{array}$ & $\begin{array}{l}-1.985 \\
(1.848)\end{array}$ \\
\hline Ln(Village Income Per Capita) & $\begin{array}{l}0.936^{*} \\
(0.261)\end{array}$ & $\begin{array}{c}0.440 \\
(0.400)\end{array}$ & $\begin{array}{c}0.897 \\
(0.368)\end{array}$ & $\begin{array}{l}-0.016^{*} \\
(0.008)\end{array}$ & $\begin{array}{l}-0.025 \\
(0.013)\end{array}$ & $\begin{array}{l}-0.015 \\
(0.013)\end{array}$ & $\begin{array}{c}0.033 \\
(0.087)\end{array}$ & $\begin{array}{l}-0.036 \\
(0.121)\end{array}$ & $\begin{array}{l}-0.016 \\
(0.136)\end{array}$ \\
\hline $\begin{array}{l}\text { Ln(Village Average Ed Per } \\
\text { Capita) }\end{array}$ & $\begin{array}{l}-0.299 \\
(0.499)\end{array}$ & $\begin{array}{l}-0.037 \\
(0.465)\end{array}$ & $\begin{array}{l}-0.278 \\
(0.435)\end{array}$ & $\begin{array}{l}-0.007 \\
(0.014)\end{array}$ & $\begin{array}{l}-0.002 \\
(0.014)\end{array}$ & $\begin{array}{l}-0.004 \\
(0.015)\end{array}$ & $\begin{array}{c}0.008 \\
(0.168)\end{array}$ & $\begin{array}{c}0.039 \\
(0.169)\end{array}$ & $\begin{array}{c}0.018 \\
(0.199)\end{array}$ \\
\hline $\begin{array}{l}\text { Agricultural Income as a Share } \\
\text { of Total Income }\end{array}$ & $\begin{array}{l}2.196^{*} \\
(0.606)\end{array}$ & $\begin{array}{l}2.231 * \\
(0.627)\end{array}$ & $\begin{array}{l}2.199 * \\
(0.624)\end{array}$ & $\begin{array}{l}0.048 * \\
(0.017)\end{array}$ & $\begin{array}{l}0.048 * \\
(0.018)\end{array}$ & $\begin{array}{l}0.060 * \\
(0.019)\end{array}$ & $\begin{array}{l}-0.231 \\
(0.202)\end{array}$ & $\begin{array}{l}-0.266 \\
(0.207)\end{array}$ & $\begin{array}{l}-0.319 \\
(0.346)\end{array}$ \\
\hline $\begin{array}{l}\text { Over-Identification } \\
\text { Chi-Square Statistic } \\
\text { (Chi-Probability) }\end{array}$ & & $\begin{array}{c}1.16 \\
(0.282)\end{array}$ & $\begin{array}{c}22.43 \\
(0.013)\end{array}$ & & $\begin{array}{c}0.74 \\
(0.391)\end{array}$ & $\begin{array}{c}25.60 \\
(0.004)\end{array}$ & & $\begin{array}{c}0.76 \\
(0.384)\end{array}$ & $\begin{array}{c}5.65 \\
(0.844)\end{array}$ \\
\hline $\begin{aligned} \text { The First Stage } & \\
\text { Ln(Vill IPC) } & \text { F-Test } \\
& \text { (F-Probability) }\end{aligned}$ & & $\begin{array}{c}17.21 \\
(0.000)\end{array}$ & $\begin{array}{c}11.01 \\
(0.000)\end{array}$ & & $\begin{array}{c}17.21 \\
(0.000)\end{array}$ & $\begin{array}{c}11.01 \\
(0.000)\end{array}$ & & $\begin{array}{c}15.50 \\
(0.000)\end{array}$ & $\begin{array}{c}8.83 \\
(0.000)\end{array}$ \\
\hline $\begin{array}{l}\text { F-Test } \\
\text { (F-Probability) }\end{array}$ & & $\begin{array}{c}31.66 \\
(0.000)\end{array}$ & $\begin{array}{c}6.41 \\
(0.000)\end{array}$ & & $\begin{array}{c}31.66 \\
(0.000)\end{array}$ & $\begin{array}{c}6.41 \\
(0.000)\end{array}$ & & $\begin{array}{c}32.00 \\
(0.000)\end{array}$ & $\begin{array}{c}5.44 \\
(0.000)\end{array}$ \\
\hline $\begin{array}{l}\mathrm{N} \\
\mathrm{R} 2\end{array}$ & $\begin{array}{c}99 \\
0.423\end{array}$ & $\begin{array}{c}99 \\
-\end{array}$ & $\begin{array}{c}99 \\
-\end{array}$ & $\begin{array}{c}100 \\
0.305\end{array}$ & $\begin{array}{c}100 \\
-\end{array}$ & $\begin{array}{c}100 \\
-\end{array}$ & $\begin{array}{c}96 \\
0.244\end{array}$ & $\begin{array}{c}96 \\
-\end{array}$ & $\begin{array}{c}96 \\
-\end{array}$ \\
\hline $\begin{array}{l}\text { Instruments: } \\
\text { Measurement Error Instruments: } \\
\text { Extended Land Instruments and As } \\
\text { cultivated land gini, cultivated lan } \\
\text { percent of hh other land (forest or } \\
\text { share of other land managed by the } \\
\text { Notes: All models include jointly } \\
\text { asterisk }(*) \text { indicates a p-value of } 1\end{array}$ & $\begin{array}{l}\text { Jinety/ten } \\
\text { set Instrun } \\
\text { l per capit: } \\
\text { fishpond la } \\
\text { collective } \\
\text { significant } \\
\text { ess than fi }\end{array}$ & $\begin{array}{l}\text { ncome per ca] } \\
\text { ents: } \ln (\text { prod } \\
\text { other land } \mathrm{p} \\
\text { nd), percent } \\
\text { province dum } \\
\text { e percent. }\end{array}$ & $\begin{array}{l}\text { a ratio, seven } \\
\text { tive assets pe } \\
\text { capita, villag } \\
\text { h other land i } \\
\text { y variables a }\end{array}$ & $\begin{array}{l}\text { e/twenty } \\
\text { ta), gini } \\
\text { rage dep } \\
\text { cted with } \\
\text { lage loca }\end{array}$ & $\begin{array}{l}\text { ive income } \\
\text { roductive as } \\
\text { dency ratio, } \\
\text { ther land pe } \\
\text { on dummy v }\end{array}$ & $\begin{array}{l}\text { capita ratio } \\
\text { s per capita) } \\
\text { efficient of } \\
\text { apita, share } \\
\text { ables. Rob }\end{array}$ & $\begin{array}{l}\text { age wag } \\
\text { of village } \\
\text { of hous } \\
\text { ated lanc } \\
\text { lard errol }\end{array}$ & $\begin{array}{l}\text { come per cap } \\
\text { sets controlle } \\
\text { ld dependenc } \\
\text { anaged by col } \\
\text { hown in paren }\end{array}$ & $\begin{array}{l}\text { y collective, } \\
\text { atios, } \\
\text { tive, and } \\
\text { eses. An }\end{array}$ \\
\hline
\end{tabular}




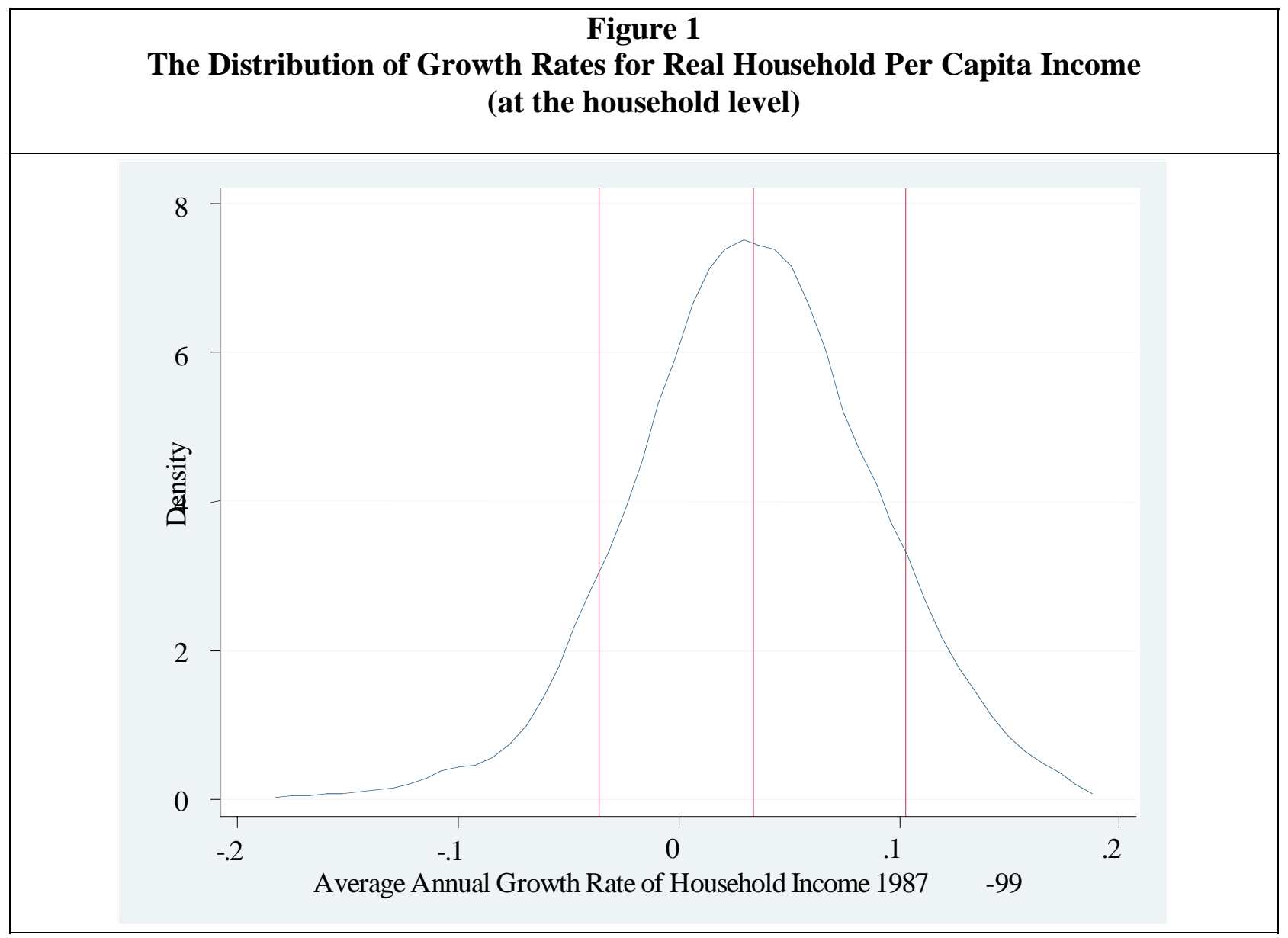

Note: vertical lines indicate the $10^{\text {th }}, 50^{\text {th }}$, and $90^{\text {th }}$ percentiles $(-0.036,0.033$, and 0.103$)$ 
Figure 2

The Distribution of Village-Level Gini Coefficients in the Initial Period

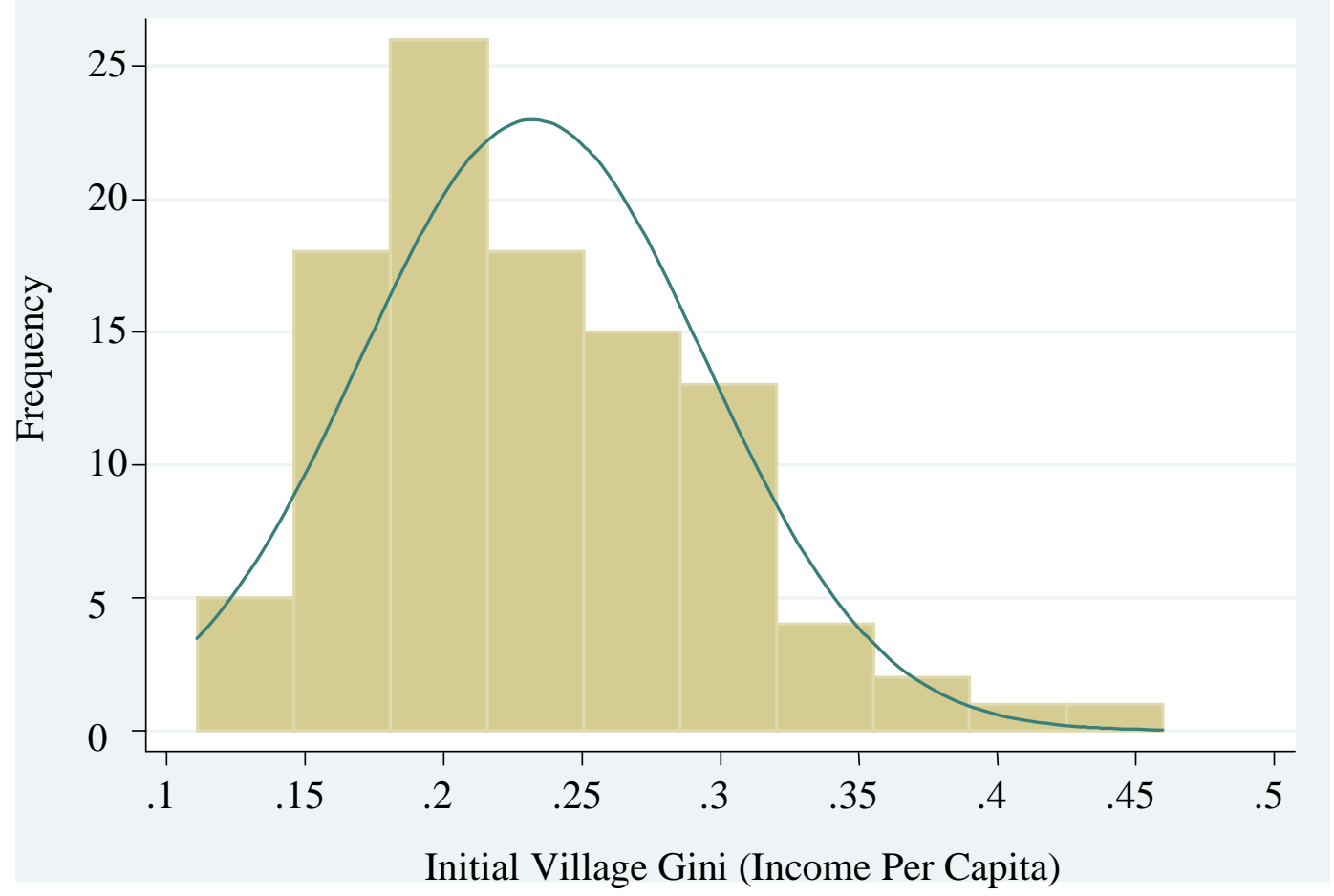


Figure 3

The Relationship Between Initial Inequality and Subsequent Growth (at the village level)

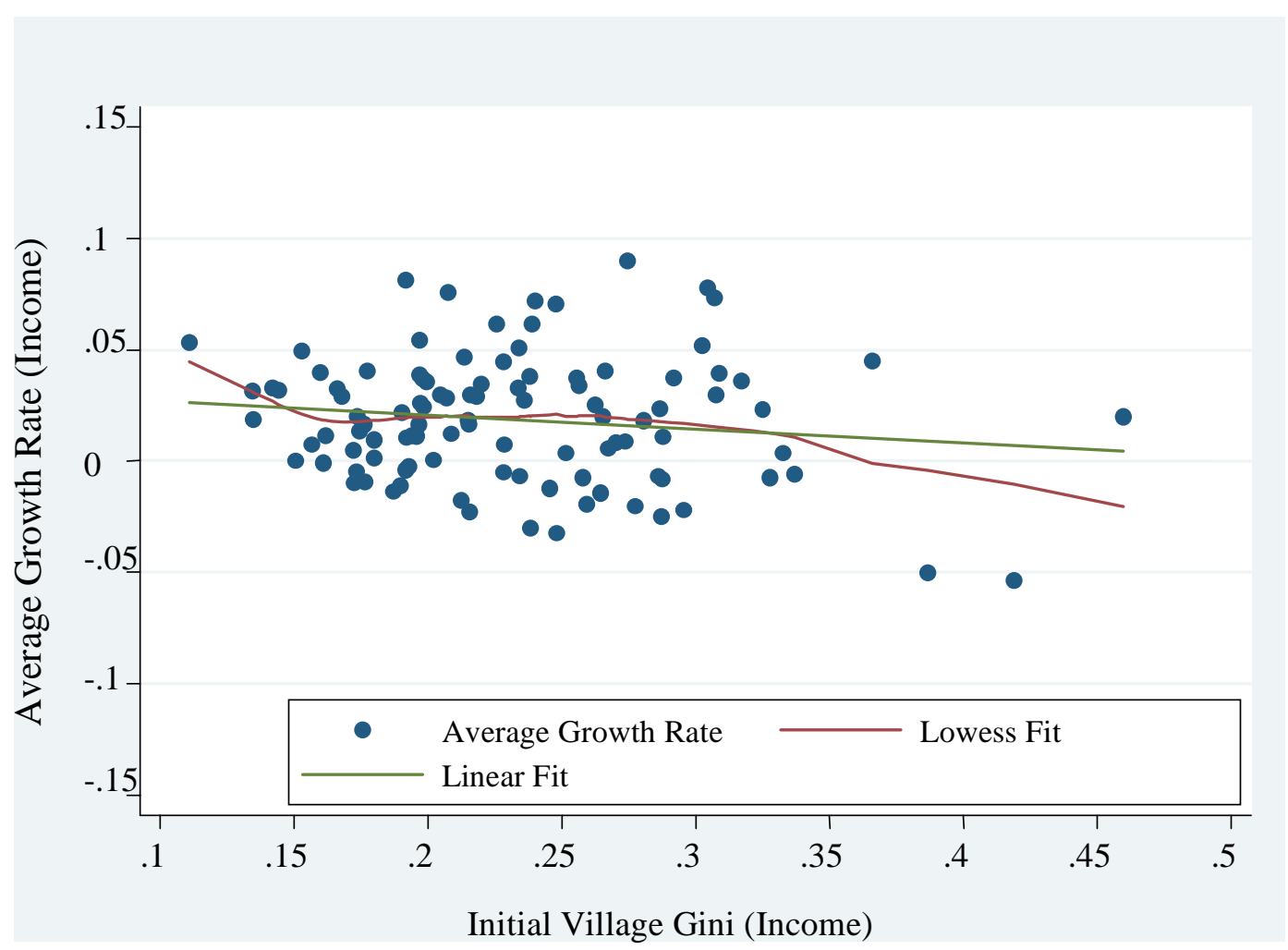

Note: The coefficient of the slope in the linear regression is $-0.063(t=1.42)$ 